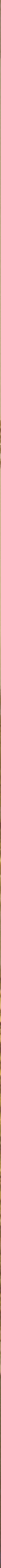




\section{Dotación, patrocinio e iconografía de la retablística de la colegiata del Sacro Monte en Granada (siglos XVII y XVIIl)}

Endowment, Patronage and Iconography of the Altarpieces of Collegiate Church of Sacro Monte in Granada (17 th and $18^{\text {th }}$ Centuries)

José María Valverde Tercedor

Universidad de Granada, España

josemvalter@gmail.com

http://orcid.org/0000-0002-4950-3552

Recepción: 31/05/2020 | Aceptación: 22/09/2020

\section{Resumen}

Los retablos de la iglesia colegial de la abadía del Sacro Monte son fiel testimonio de los avatares que sufrió durante los siglos XVII y XVIII, como consecuencia de la defensa de los libros plúmbeos. En este artículo, a través de documentos inéditos, además de su iconografía, conocemos a los artistas que intervinieron en ellos, desde Miguel Cano o Pedro de Raxis, hasta Francisco de Paula Castillo y Pedro Valero. También ponderamos la ingente labor de patrocinio y mecenazgo llevada a cabo por sus abades y canónigos, entre otros, Pedro de Ávila y Francisco de Barahona en el XVII, y Vázquez de Figueroa o López de Mesa en el XVIII. A estos unimos las donaciones de particulares, fundamentales en la configuración de los altares del templo.

\section{Abstract}

The altarpieces of church of the Sacro Mnte Abbey are a faithful testimony of the upheavals it underwent during the $17^{\text {th }}$ and $18^{\text {th }}$ centuries as a consequence of the defence of its Lead Books. This article offers first-hand knowledge of both the artists of the altarpieces such as Miguel Cano, Pedro de Raxis, Francisco de Paula Castillo, Pedro Valero, etc. and their iconography, through many previously unpublished documents. Sponsorship and patronage actions performed by abbots and canons such as Pedro de Ávila y Francisco de Barahona (17 $7^{\text {th }}$ century) or Vázquez de Figueroa and López de Mesa (18 $8^{\text {th }}$ century) are also documented. Among them, it should be noted that individual donations were crucial for the temple's altars.

\section{Palabras clave}

Retablística

Granada

Abadía del Sacro Monte

Barroco

Siglo XVII

Siglo XVIII

\section{Keywords}

\section{Altarpieces}

Granada

Sacro Monte Abbey

Baroque

$17^{\text {th }}$ Century

$18^{\text {th }}$ Century 


\section{La retablística sacromontana: de la fundación al siglo XVIII}

Las primeras aportaciones a la retablística sacromontana surgieron a raíz de su erección en 1610, de la mano de arquitectos-ensambladores, escultores y pintores de primer orden, que se afanaron en dotar de un canal catequético-doctrinal al templo recién edificado, mediante el empleo de un simpar lenguaje plástico. Algunos fueron llamados de Sevilla por el arzobispo fundador, Pedro de Castro², como los ensambladores de retablos Francisco Díaz del Rivero o Miguel Cano (padre de Alonso Cano) quien, procedente de Almodóvar del Campo, estuvo en Granada desde 1587. Asentado en la capital andaluza en 1615, allí falleció en $1646^{3}$. También fue muy destacado el alcalaíno Pedro de Raxis. Considerado por Francisco Pacheco "uno de los mejores artistas dedicados a pintar retablos y estofar imágenes, lo que hacía con tal preciosismo que en Granada se le llamaba el padre de la estofa". Se ocupó de dotar de una singular riqueza plástica a estas fábricas ${ }^{4}$. Junto a ellos intervinieron célebres imagineros granadinos como Pablo de Rojas o Bernabé de Gaviria. Todos trabajaron prolíficamente en el revestimiento de la arquitectura de Ambrosio de Vico actuando, además de en la abadía, en muchas iglesias de la archidiócesis granadina como motor esencial en la reconstrucción y renovación de estas, provocada, en gran medida, por la rebelión morisca, e impulsada por Castro a finales del siglo XVI ${ }^{5}$. Estéticamente la creación de estos artífices denota un barroco atemperado, sometido en ocasiones a líneas manieristas. Este matiz también es patente en los pintores Juan Sánchez Cotán y Vicente Carducho, quienes despuntaron en el ámbito de la cartuja de Granada, convirtiéndose en grandes exponentes del proto-naturalismo ${ }^{6}$.

Los retablos de la iglesia del Sacro Monte en los que se concentró la actividad de estos artistas: Ios colaterales y el mayor, hoy desgraciadamente han desaparecido. No obstante, conservamos importantes testimonios documentales y algunos significativos vestigios materiales de su antiguo esplendor: pinturas, esculturas y altares. La causa

1. Este artículo recoge los resultados de: José María Valverde Tercedor, "El arte como legado, patrocinio y mecenazgo en la Abadía del Sacro Monte. Siglos XVII y XVIII" (tesis doctoral, Universidad de Granada, 2019), consultado el 17 de mayo de 2020, https://dialnet. unirioja.es/servlet/tesis?codigo=221457

2. Pedro de Castro (1534-1623) fue el arzobispo de Granada entre 1590 y 1610 , ocupando consecutivamente la silla de la capital andaluza, hasta su defunción.

3. Antonio Gallego Burín, El Barroco granadino (Granada: Comares, 1987), 61 y 70-71.

4. Gallego y Burín, 64.

5. Ambrosio de Vico ocupó los cargos de maestro mayor y veedor de las iglesias. Este último le fue otorgado en 1593 y lo conservó hasta 1621 en que fue sustituido por Bernabé de Gaviria. José Manuel Gómez-Moreno Calera, El Arquitecto granadino Ambrosio de Vico (Granada: Universidad, 1992), 49-50.

6. Emilio Orozco Díaz, El pintor fray Juan Sánchez Cotán (Granada: Universidad de Granada, 1993). 
principal de su pérdida fue una obligada relectura de su iconografía, directamente derivada de los libros plúmbeos, a raíz del acalorado debate entre eruditos y teólogos, surgido en torno a ellos durante el Seiscientos. Los libros del Sacro Monte son unas planchas de plomo que aparecieron junto a las reliquias de los varones apostólicos san Cecilio, san Hiscio, san Tesifón y sus compañeros mártires, entre los años 1595-1599 y dieron lugar a la fundación de la abadía. El problema estaba en que su contenido doctrinal, además de exaltar ciertas devociones propias de la Reforma católica, introdujo otras nuevas, más polémicas, llamadas a estrechar lazos entre el cristianismo y el islam. Pronto fueron relacionados con los hallazgos acaecidos en 1588 al derribar la torre Turpiana de la catedral y colocaban a Granada en el centro de la evangelización de Hispania, denotando atrevidas aspiraciones a convertirse en un quinto evangelio ${ }^{7}$. Conducidos para su análisis, primero a Madrid y luego a Roma, fueron finalmente condenados como heréticos en 1682 por Inocencio XI.

En cuanto al mecenazgo y patrocinio de estos retablos, figura en primer lugar el propio Pedro de Castro, quien hizo una ingente cantidad de donaciones inter vivos a la abadía, desde finales del siglo XVI, ratificándolas y aumentándolas en su testamento, en $1620^{8}$. Este afán por privilegiar la institución que había fundado y a la que consideró propia, le condujo a enfrentarse con la Iglesia sevillana, que en más de una ocasión le acusó de beneficiarse de ella, en favor de Granada ${ }^{9}$. Los proyectos de Castro contaron con el asesoramiento de los canónigos de la primera canonjía, nombrados directamente por él, quienes lo visitaron continuamente a Sevilla. Entre ellos fueron los más destacados Justino Antolínez de Burgos (primer abad de la institución), Francisco de Barahona ( primer canónigo obrero)y Pedro de Ávila (primer abad electo). El último destaca sobremanera, al demostrar un más que llamativo interés por el coleccionismo y un exquisito gusto artístico. Entre otras obras, costeó el dorado de los altares colaterales y seguramente a su influencia se debe el elenco de artistas que intervinieron ${ }^{10}$.

El segundo impulso a la retablística sacromontana fue en el siglo XVIII. Momento en que el patrocinio tuvo dos ramas perfectamente diferenciadas. Por un lado se encuentran

7. José de Ramos López, El Sacro-Monte de Granada (Madrid: Fortanet, 1883).

8. María Luisa García Valverde, "La donación del arzobispo don Pedro de Castro al Sacromonte: el inventario de sus bienes," Cuadernos de Arte, no. 27 (1996): 283-295.

9. Alonso Sánchez Gordillo, Memorial sumario de los arzobispos de Sevilla y otras obras (facsímil, Sevilla: Ayuntamiento, 2003), 242; José Antonio Ollero Pina, "Don Pedro de Castro, arzobispo de Sevilla (1610-1623), una relación conflictiva," en Realidades conflictivas. AndaIucía y América en la España del Barroco, eds. Miguel Luis López-Guadalupe y Juan José Iglesias Rodríguez (Sevilla: Universidad, 2012), 95-116.

10. Zótico Royo Campos, Abades del Sacro-Monte (Granada: Anel, 1964), 38. 
Ios sacromontanos como el abad Gaspar Salcedo (1743-1761) y el que fue rector del colegio durante su mandato, Antonio López Chinchilla, abad en 1776. Gregorio Eugenio de Espínola, quien fuera antiguo colegial y beneficiado de la Virgen de las Angustias" ${ }^{11}$. Manuel López de Mesa, que fue colegial del Sacro Monte, capellán y canónigo (1761-1800)12. Martín Vázquez de Figueroa y Peralta, quien fue canónigo desde 1736 y abad desde el 3 de marzo de 1762, en que sustituyó a Luis Francisco de Viana y Bustos, hasta 177613, y el canónigo y también colegial Antonio Sánchez Fernández ${ }^{14}$. Por otra parte están los laicos, en su mayoría pertenecientes a la alta sociedad como la marquesa de Villamanrique o Félix Padilla Barrionuevo, estuvieron en muchos casos emparentados con los capitulares. Todos fueron movidos por devoción a los mártires, aunque también por beneficios más mundanos, como obtener acceso al prestigioso Colegio-Seminario de teólogos y juristas de san Dionisio Areopagita, cuyos estudios se vieron considerablemente ampliados y favorecidos en 1752, especializándose, entre otras disciplinas, en lenguas orientales ${ }^{15}$.

Así pues, el resurgir patrimonial de la abadía, iniciado por el arzobispo Martín de Ascargorta, a finales del siglo XVII, vino acompañado por la redacción de diversos textos apologistas, conocidos como los Defensorios, durante la mayor parte del XVIII. Consistieron en unos escritos que ponderaban los postulados doctrinales del Sacro Monte, enalteciendo sus propios orígenes, para reparar la maltrecha reputación de la abadía y devolverle su esplendor ${ }^{16}$. Fueron iniciados por Diego de la Serna Cantoral con las Vindicas Católicas Granatenses y seguidos por importantes canónigos como Luis Francisco de Viana o José de Laboraria. Además, algunos de los religiosos acompañaron a Juan de Flores, canónigo de la catedral, en las aventuras falsarias de la alcazaba Qadima17. Unas excavaciones comenzadas en 1754, con antecedentes en 1621 y que dieron como fruto la aparición de unas ruinas de un edificio, vestigios del concilio de Elvira y unas planchas de plomo, asociadas a las del Monte Santo. Contaron con la reticencia de mentes ilustradas y se enfrentaron desde el principio a importantes obstáculos

11. Libro de Abades y Canónigos, 150v, Fondo Abadía, Archivo Abadía del Sacro Monte (AAS), Granada.

12. Libro de Abades y Canónigos, $183 r$.

13. Libro de Abades y Canónigos, 20r-v y 83v-84r.

14. Libro de registro de entrada de colegiales, 128r, Fondo Colegio, legajo 91, 2, Archivo Abadía del Sacro Monte (AAS), Granada.

15. José de Ramos López, Restablecimiento de los estudios de derecho en el insigne colegio del Sacro-Monte de Granada (Granada: José López Guevara, 1897).

16. Juan Sánchez Ocaña, El Sacro Monte de Granada, imaginación y realidad (Granada: Ayuntamiento, 2007), 112-120.

17. Según se ha dicho, en los mismos confluyen intereses políticos, tanto locales como nacionales. Gloria Mora y Joaquín Álvarez Barrientos, "Las falsificaciones granadinas del siglo XVIII. Nacionalismo y arqueología," Al-Oantara XXIV, no. 2 (2003): 533-546; José Manuel Roldán Hervás, "Arqueología y fraude en la Granada del siglo XVIII: Juan de Flores y las excavaciones del Albayzín," Zephyrvs, no. 85 (1984): 377-396; Libro de Abades y Canónigos, 181v. 
legales ${ }^{18}$. La principal de todas fue en 1763, con el descubrimiento de nuevas planchas, y otros restos ligados al dogma de la Inmaculada. Dada su poca credibilidad, fueron condenadas en 1774, con sentencia final de 6 de marzo de $1777^{19}$.

Estas vicisitudes tuvieron su plasmación en los retablos del siglo XVIII. Sustitutos de los anteriores, vinieron a decorar y dotar de mensaje los numerosos proyectos arquitectónicos que, en tiempos del abad Martín Vázquez de Figueroa, se programaron, actuando como libros plásticos, ilustradores de la nueva y vieja historia sacromontana, y motivando el predominio del Setecientos en la estética del templo ${ }^{20}$. Especialmente significativa fue la ampliación de la iglesia en 1763, con la que pasó de una sola a tres naves, gracias al impulso del canónigo Manuel López de Mesa ${ }^{21}$. Con ello se paliaba, aunque con matices, el proyecto frustrado del jesuita Pedro Sánchez, quien, a comienzos del siglo XVII, y auspiciado por el propio Pedro de Castro, ideó una gran iglesia de peregrinación para el Sacro Monte. Así pues, la antesala al resurgir retablístico dieciochesco de la abadía lo protagonizaron el retablo de la Virgen del Rosario y el mayor. Siguieron su estela los colaterales, de la Inmaculada y san José, el del Santo Cristo y el de la capilla del reservado. De todo lo señalado se deduce que la principal motivación de la mutación artística del Sacro Monte fue su intrahistoria. Más allá de parámetros formales, no cabe duda de que los canónigos sacromontanos reflejaron a través del arte sus propias inquietudes, con funciones altamente didácticas y con la aspiración moralizante que acompañó siempre a la Reforma católica. Es por eso que la estética de los retablos comparte la tendencia estilística promovida por los talleres activos en la Granada de los siglos XVII y XVIII, siendo en el plano propiamente técnico fiel reflejo de ella. En cuanto a los temas, evolucionarán con el tránsito de los siglos, de la exaltación más fiel del mensaje de los plomos de sus inicios, a una iconografía mucho más ortodoxa y conjuntamente más amable y popular, aunque en algunos como el retablo mayor siguió viva una elocuente apología martirial.

18. Gloria Mora y Joaquín Álvarez Barrientos, "Las falsificaciones granadinas del siglo XVIII. Nacionalismo y Arqueología," en Los plomos del Sacromonte. Invención y tesoro, eds. Manuel Barrios Aguilera y Mercedes García-Arenal (Valencia: Universidad de Valencia, 2006), 524.

19. Como consecuencia fueron condenados Juan de Flores, quien fue públicamente humillado, situación que se agravó por la enfermedad que padecía, y los clérigos Medina Conde y Velázquez de Echeverría a penas de inhabilitación y reclusión. Manuel Sotomayor, Don Juan de Flores y Oddouz Pícaro y mártir, Cultura y picaresca en la Granada de la llustración (Granada: Universidad de Granada, 2008), 255286; Manuel Barrios Aguilera y Mauricio Pastor Muñoz, eds., Razón del juicio seguido contra los falsificadores de la Alcazaba del Albaicín (Granada: Universidad de Granada, 2017), VII-XXIII.

20. "Crónica del Centro," Boletín del Centro artístico de Granada, no. 6 (1886): 1. Junto a los retablos que estudiamos en este artículo, en el siglo XVIII se redecoró la iglesia con yeso tallado con motivos ondulados, placas recortadas y numerosos sellos salomónicos. Gómez-Moreno Calera, El Arquitecto granadino, 46.

21. A este periodo se deben, además de los referidos retablos colaterales y retablo de la capilla del reservado, el retablo del Santo Cristo y el cancel y puertas del crucero y el blanqueo y soldado de la iglesia. Libro de Abades y Canónigos, 20r-v. Véase: Royo Campos, Abades, 159. 


\section{Retablos colaterales}

\section{Primigenios}

El Sacro Monte contó en sus orígenes con dos altares colaterales: el del sagrario, ubicado en la nave de la epístola del crucero ${ }^{22}$ y el de la Inmaculada, en la del evangelio. Contaban con retablos propios donde intervinieron Miguel Cano y Pedro de Raxis. Esta valiosa información constituye una gran novedad, dado que hasta el momento se sabía poco de ellos, llegándose incluso a pesar que constituían uno solo. Estos retablos, en sí mismos, eran un alegato en favor de los libros plúmbeos, y en su conformación combinaban pintura y escultura. En cuanto al asunto principal al que estaban consagrados: la Inmaculada Concepción y el sagrario, privilegiaba dos devociones propias de la Reforma católica, con extraordinaria presencia en la abadía, según mandaban sus constituciones. La devoción sacramental, presente en toda institución cenobítica que se precie, aquí cobraba un especial sentido, por su empatía con los mártires. No olvidemos que Cristo es el primero de todos y su inmolación se renueva en el sacrificio eucarístico. De este periodo conservamos un sagrario, casi con toda seguridad perteneciente a estos altares primitivos, y atribuible a Miguel Cano. En madera dorada, posee formas arquitectónicas, como denota su puerta, de líneas rectas, rotas por un arco de medio punto central, y flanqueada por dos esbeltas columnas sobre plinto que sustentan un entablamento. Está decorado por un relieve donde se representa un ostensorio sobre el cordero místico o apocalíptico, reposado en el libro de los siete sellos, como es habitual (Fig. 1). Su cara interna, de gran belleza decorativa, está formada por un jarrón inciso y matizado en oro, con azucenas, según las formas propias de Pedro de Raxis.

El altar privilegiado de la Inmaculada fue consagrado en 1615. Recordemos que estábamos inmersos en los años de gran exaltación concepcionista hispana, y que estos, en gran parte vinieron impulsados por los descubrimientos de la abadía y fueron favorecidos desde Sevilla por Pedro de Castro. Así pues, en este altar fue enorme la implicación de todos los capitulares, como ejemplifica el cabildo de 7 de agosto, en que el canónigo del periodo fundacional Gabriel Ledesma se comprometió a la dotación de un aniversario a la Inmaculada (con carácter de perpetuidad), "el día de la dedicación del altar de Nuestra Señora de la Concepción, que aora se quiere dedicar en este Sacro Monte en la capilla mayor del, en

22. La rareza en la disposición del altar del sagrario pudo estar motivada por su correspondencia ritual con el espacio que da acceso a las Santas Cuevas. 
el altar colateral del cruzero de mano derecha del altar mayor ${ }^{\prime \prime 2}$. Finalmente, gracias al cabildo de 10 de octubre, nos consta que en la fiesta de su dedicación actuó como comisario el mismo Ledesma, junto a Agustín Manrique, contando con la predicación de Francisco de Barahona ${ }^{24}$. Según las cuentas de la abadía, sabemos que el retablo que lo presidía estaba formado por un cuadro de la Inmaculada de Pedro de Raxis ${ }^{25}$ y la guarnición de su marco la hizo Miguel Cano, a quien en este momento se le reconoce como escultor en un asiento del año de 1615, donde se hacen constar los"seiscientos reales ${ }^{\prime \prime 6}$ que por libranza de 29 de mayo se le dieron.

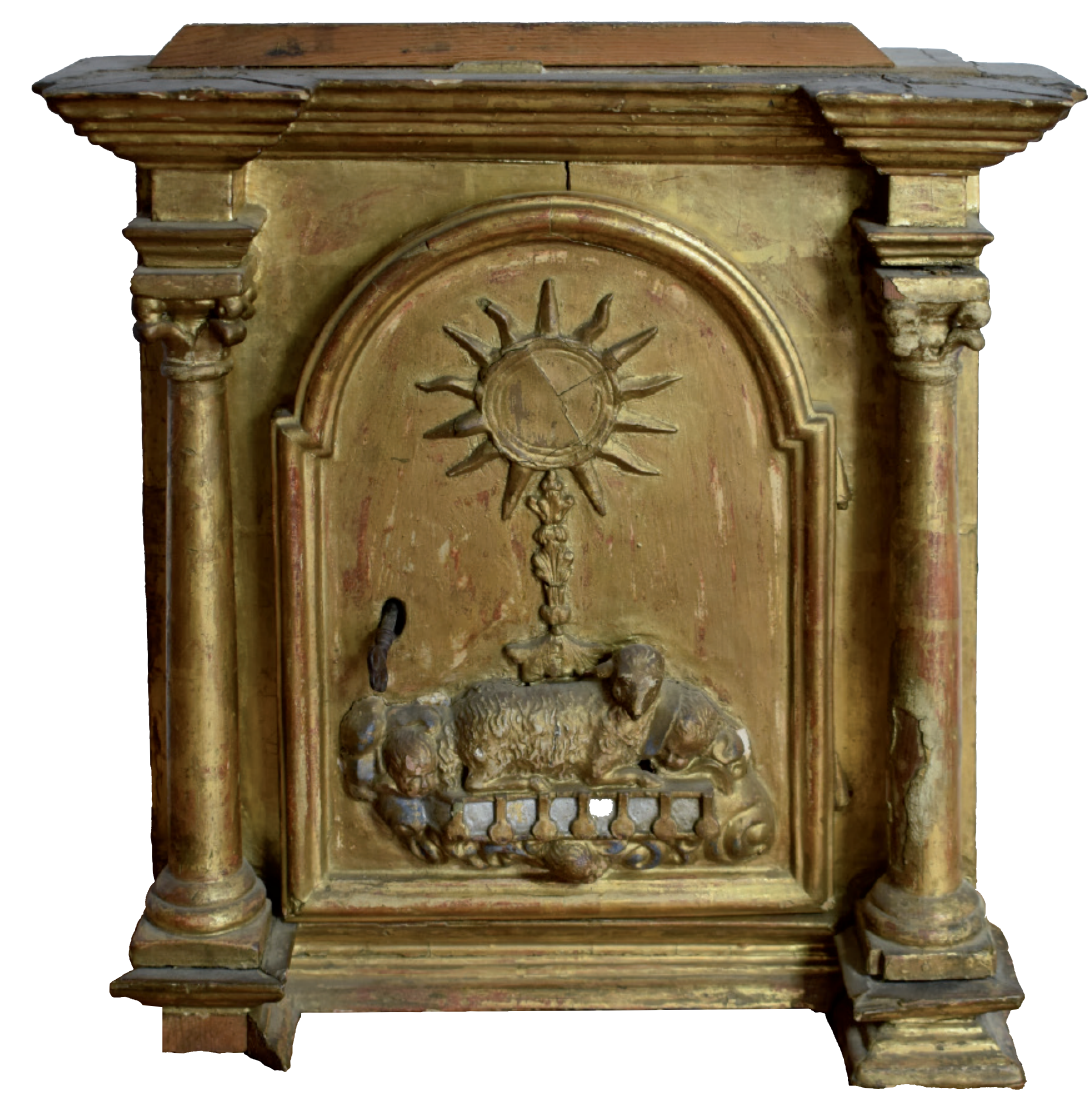

Fig. 1. Miguel Cano, Sagrario, primera mitad del siglo XVII. Madera dorada. Abadía del Sacro Monte, Granada.

Por su parte, los pagos del retablo del sagrario se demoraron hasta el 30 de noviembre de 1618. Según un asiento de dicho año, fueron abonados 33 reales a Miguel Cano y a la criada de Fernando de Ávila ${ }^{27}$, Juana del Castillo. Unidos a los 30 que se dieron al carpintero Pedro Arriano ${ }^{28}$,"y con seteçientos que el año de 616 se le dieron, según parece del libro de la raçón viejo, asiento 108, se le acaban de pagar 765 reales en que se concertó el retablo de madera que hizo para el altar del sagrario"29. Al igual que en el de la Inmaculada de las Cuevas, hecho en este mismo periodo, en el dorado, estofado y policromado del retablo y de los tres medios cuerpos que lo componían (entre los que se identifica el de san Mesitón), se contó con los trabajos de Pedro de Raxis, procediendo el oro de Antonio Carrasco ${ }^{30}$.

23. Actas Capitulares 1, 1615-08-07, 117v, leg. 258, Archivo Abadía del Sacro Monte (AAS), Granada.

24. Actas Capitulares 1, 1615-10-01, 123r.

25. Libro de cuentas (arcas), 92r, leg. 214, Archivo Abadía del Sacro Monte (AAS), Granada. Véase: Isaac Palomino Ruiz y José Antonio Peinado Guzmán, "Referencias documentales en torno a la dotación artística primigenia de la abadía del Sacro Monte en Granada," Revista de Humanidades, no. 29 (2016): 45.

26. Libro de cuentas (arcas), 89r.

27. Fue caballero veinticuatro de Granada y sobrino de Pedro de Ávila.

28. Fue el carpintero más activo en el Sacro Monte estos años, como demuestran sus labores en el monumento del Jueves Santo o la sillería del coro.

29. Cuentas 1618-1631, 53v, leg. 220, Archivo Abadía del Sacro Monte (AAS), Granada.

30. Libro de cuentas (arcas), 48r y 111r-144v. Palomino Ruiz y Peinado Guzmán, "Referencias documentales," 37-60. 


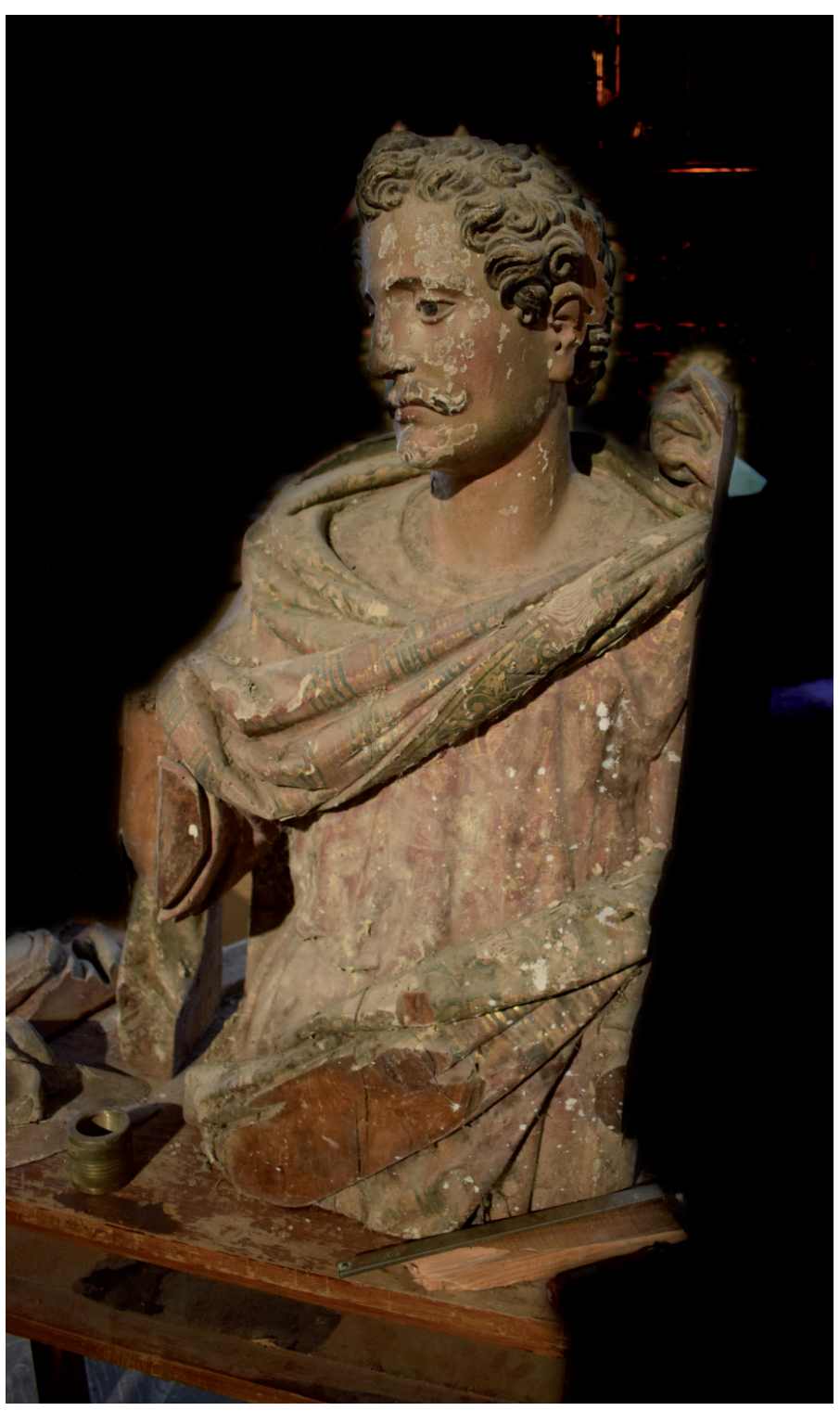

Fig. 2. Bernabé de Gaviria (atribución) y Pedro de Raxis, ¿San Mesitón?, primera mitad del siglo XVII. Madera tallada, estofada y policromada. Abadía del Sacro Monte, Granada. Fotografía anterior a su reciente restauración.
Es muy probable que uno de estos medios cuerpos sea la figura masculina inédita que, con apariencia de romano, se conserva en una dependencia colindante con las crujías de la abadía. Imagen de rostro ensimismado y bigote perfilado, denota un naturalismo incipiente. Tiene una cabellera formada por amplios y llamativos bucles y un exquisito estofado (Fig.2). En cuanto a su autoría, a pesar de su formato reducido, de busto largo, algunos detalles como los pliegues de las mangas de su túnica, desarrollados en varios anillos sucesivos, invitan a relacionarlo con el arte de Bernabé de Gaviria. Escultor en Granada entre 1603 y 1622, discípulo y continuador de Pablo de Rojas, fue colaborador muy habitual de Miguel Cano y de Pedro de Raxis. Se han podido documentar, diferentes trabajos suyos como su labor en el retablo del convento Casa Grande de San Francisco ${ }^{31}$. Por último, no hay duda de que en la obra que nos ocu-

pa, además de la exquisita finura de su modelado, destacan las carnaciones y estofados, donde es evidente la mano del propio Raxis. Esto lo observamos, por ejemplo, en la túnica roja, cuyo diseño nos evoca al mantolín del san Juan de Albolote. Como se ha dicho ut supra, este retablo vino a embellecer y a dotar de mensaje doctrinal el altar del sagrario, cuya consagración se remonta a la bendición del templo. En concreto, en el cabildo de 19 de octubre de 1610, se hace constar que el 22 de agosto, octava de la Asunción, el arzobispo

31. Véase: Lázaro Gila Medina, "Aproximación a la vida y obra del pintor y estofador alcalaíno-granadino Pedro Raxis," Archivo Español de Arte, no. 304 (2003): 389-406; Lázaro Gila Medina, "Bernabé de Gaviria: continuación y ruptura de los ideales de Rojas," en La escultura del primer naturalismo en Andalucía e Hispanoamérica (1580-1625), ed. Lázaro Gila Medina (Madrid: Arco Libros, 2010), 192; Lázaro Gila Medina, "Los comienzos -bautismo y entorno familiar-y los últimos momentos -testamento y sepelio- del escultor Bernabé de Gaviria," Cuadernos de Arte, no. 38 (2007): 306. 
"dixo misa rezada a esta festividad en el altar colateral del cruzero de la capilla mayor que está en el lado de la epístola y puso también en él el Santísimo Sacramento en vn sagrario que está en el medio del dicho altar, para que de allí se administre al pueblo"32. En esta misma línea, en el cabildo de 15 de noviembre, en relación a las dos piedras "baçares" grandes que donó Pedro de Castro, se expresó su deseo de que una de ellas"se engastase en plata y se ponga en el sagrario del altar colateral"33.

Como prueba de la correspondencia entre ambos altares y de las mutaciones que experimentaron, conviene saber, que el cabildo de 17 de enero de 1617, a colación del traslado de una lámpara donada por el caballero veinticuatro Pedro González de Castilla, y que es fiel reflejo de la estrecha relación que desde este periodo existió entre el concejo municipal y la abadía, se le propuso que "se mudase del lugar donde está oy, adelante del sagrario que está en el altar colateral de la mano derecha, porque parece conuenir así para que se encienda la del altar de la limpia Concepción, o que se mude delante el altar maior en medio del pabimento"34. Por último, en cabildo de 1 de septiembre de 1625, se habla de la compra de dos alfombras para los altares colaterales, "que se emparejen y adoben las peanas del altar del sagrario, oy puerta de la iglesia"35. Estas citas inéditas, de gran valía, nos ayudan a tomar consciencia del tratamiento excepcional y privilegiado que desde los albores de la institución se dio a los altares colaterales. Esto no es de extrañar, dado que encarnaban los valores fundamentales de la abadía y su propia esencia doctrinal.

Junto a todos los datos aportados, es de sumo interés una preciosísima descripción de Alonso González de Aradillas, a propósito de un informe que hizo "de pedimiento del señor don Adán Centurión, Marqués de Estepa", por orden de Pedro de Castro. Hombre que contó con gran importancia en la segunda década de la abadía. Era de origen extremeño y fue canónigo desde el 31 de julio de 1622 hasta 1648, ejerciendo el oficio de secretario. Vistió la beca del Colegio de San Ambrosio de Sevilla, ciudad donde entró en contacto con el fundador. Sus habilidades para los idiomas le hicieron interpretar los libros plúmbeos ${ }^{36}$. Al retablo del sagrario nos lo describe como un tabernáculo flanqueado por dos lienzos. Concretamente un cuadro donde figuran "Cristo nuestro señor, acompañado de sus apóstoles, como que baxan de un castillo donde está pintado a lo lexos, haciendo el milagro de la salud de los diez leprosos que refiere san Lucas

32. Actas Capitulares 1, 1610-10-19, 18r.

33. Actas Capitulares 1, 1610-11-15, 19v.

34. Actas Capitulares 1, 1617-01-17, 147v.

35. Actas Capitulares 1, 1625-09-1, 471v.

36. Libro de Abades y Canónigos, 416r-v. 


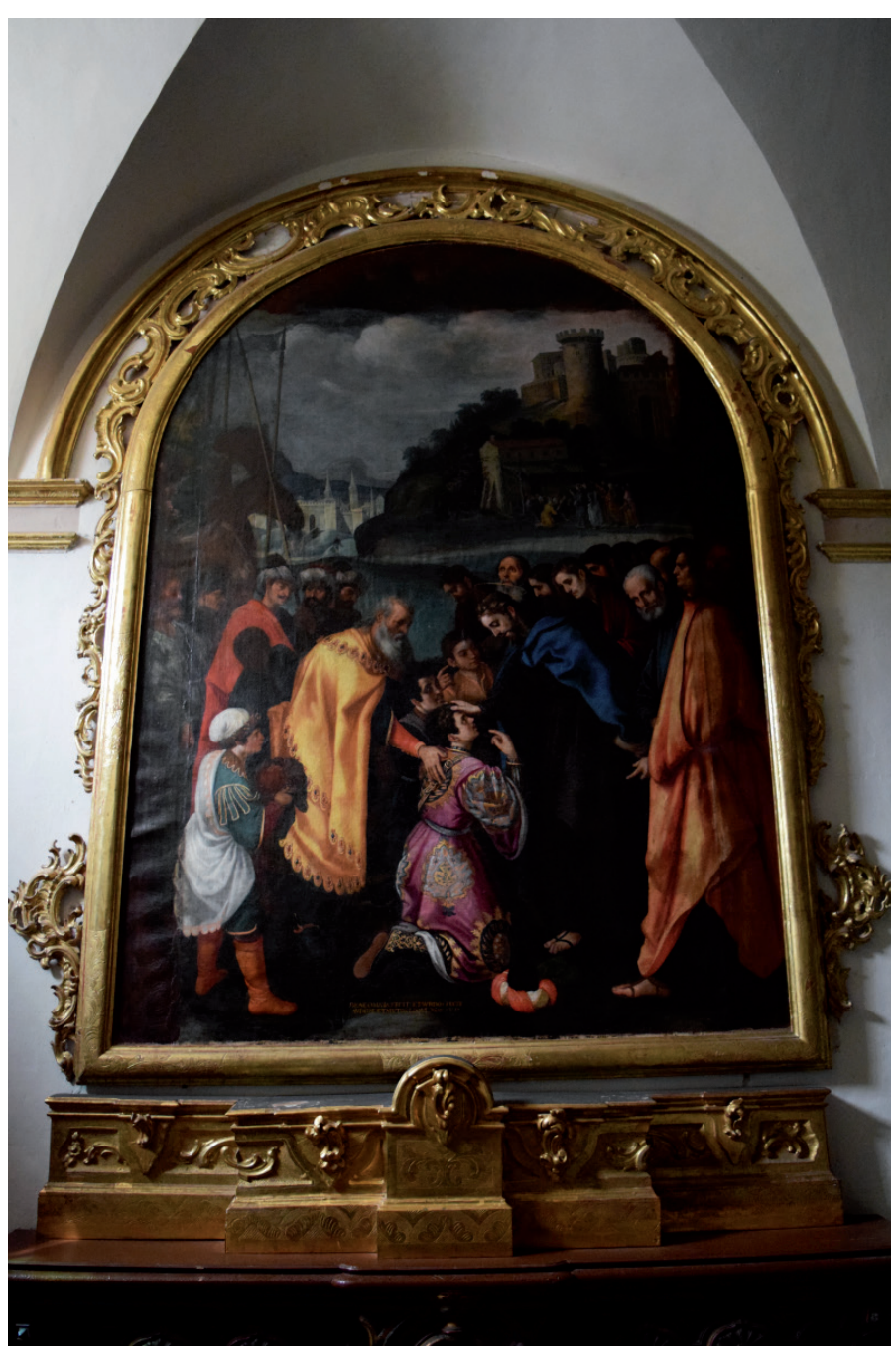

Fig. 3. Pedro de Raxis, Curación de San Cecilio y San Tesifón, primera mitad del siglo XVII. Óleo sobre lienzo. Abadía del Sacro Monte, Granada. en el capítulo 17"37. Seguidamente "san Cecilio, i san Tesifón, en edad de mancebos, el uno ciego i el orto con semblante de que es mudo i con ellos su padre que los presenta a Cristo nuestro señor, el cual los tiene delante de sí hincados de rodillas, con muestras i acción de que les está dando salud". A continuación, Aradillas expresa que "a la mano derecha del tabernáculo del Santísimo Sacramento están pintados los santos siete primeros obispos de España, discípulos del apóstol Santiago, i el apóstol san Pedro sentado en una silla vestido de pontifical consagrándolos en obispos". Apareciendo, "a la mano siniestra, pintado el Sacro Monte i se ven los mismos santos sobre él, con sus insignias i vestidos pontificales i letras que señalan el nombre i obispado de cada uno".

La primera de las pinturas corresponde, sin duda, al lienzo de la Curación de san Cecilio y san Tesifón (Fig.3), y cuya atribución a Pedro de Raxis queda confirmada en este estudio. Ha sido considerada la primitiva representación que el cabildo encargó para la abadía del Sacro Monte ${ }^{38}$. Su composición está basada en un grabado de Francisco Heylan y tiene su origen en los libros plúmbeos ${ }^{39}$. Concretamente, pertenece al Libro de los Actos de Nuestro Señor ${ }^{40}$. Actualmente está situado en el lado del evangelio de la iglesia, sobre un altar esbozado por líneas geométricas de corte manierista, de madera

37. Las siguientes referencias corresponden a: Descripción de los altares del Sacro Monte de Alonso González de Aradillas (borrador), $1.081 \mathrm{r}-\mathrm{v}$, leg. 5, 2, Archivo Abadía del Sacro Monte (AAS), Granada.

38. Francisco Javier Martínez Medina, Cristianos y musulmanes en la Granada del XVI, una ciudad intercultural (Granada: Facultad de Teología, 2016), 259.

39. Se hizo según diseño de Girolamo Lucenti, para la Historia Eclesiástica de Granada de Justino Antolínez. Antonio Moreno Garrido, y Ana María Pérez Galdeano, "Los Países Bajos y su influencia en la obra gráfica peninsular del siglo XVII," en Arte y Cultura en la Granada Renacentista y Barroca: relaciones e influencia, ed. Policarpo Cruz Cabrera (Granada: Universidad de Granada, 2014), 298.

40. Martínez Medina, Cristianos y musulmanes, 256. 
oscura policromada, donde se intuye la mano de Raxis. Es muy probable que fuese el original del retablo ${ }^{4}$. El otro lienzo respondía a la iconografía tradicional de la consagración de los varones apostólicos, con la licencia plúmbea de situarlos sobre el Sacro Monte. La leyenda de los varones apostólicos atribuye el origen del cristianismo en el sur de España a siete discípulos de Pedro y Pablo y ha constituido el principal fundamento para considerar a Cecilio el primer obispo de Granada y situarlo en el siglo $1^{42}$. Aunque se conservan varias representaciones de este tema en la abadía, ninguna parece concordar claramente con la narración.

A continuación, González de Aradillas describe "otro altar i en él un cuadro de la Inmaculada Concepción de Nuestra Señora, i al pie del está una tarjeta relevada, en la cual están escritas estas letras árabes, i debajo dellas otras castellanas que dizen así: A María no tocó el pecado primero". Acto seguido reconoce que en el lado derecho de la tarjeta "está san Cecilio vestido de pontifical, en la mano siniestra un libro redondo de plomo i en la destra un puntero de hierro, tiene el rostro levantado puestos los ojos en la Virgen". Junto a él, "al lado siniestro de la dicha targeta san Tesifón con roquete, muceta y pectoral, sobre una mesa tiene un libro redondo de plomo, escribiendo con un puntero de hierro". Probablemente ambos santos, como autores de los libros plúmbeos, se dispusiesen en lienzos diferenciados completando el retablo. En cuanto a la Inmaculada Concepción (Fig.4), hechura de Raxis que lo presidió, impulsado por una teoría atrevida pero no por ello infundada, creo acertado pensar en que fuese la que, con aires orientalizantes, palpables especialmente en su tocado, "a la egipcia", se conserva en la escalera principal del espacio tradicionalmente reservado a los canónigos del Sacro Monte $^{43}$. Refuerzan esta hipótesis su místico semblante con mirada elevada, tan propio de Raxis, y las inscripciones que, pese a su mejorable estado de conservación, se pueden leer a sus pies, tanto en árabe como en castellano, en una filacteria. Las mismas encajan a la perfección con la descripción de Aradillas ${ }^{44}$. Por último, también encuentro rasgos inequívocos del autor en el rico dorado que, a la manera del estofado de las

41. Sobre el grabado véase: Ana María Pérez Galdeano, La Historia de la Abadía del Sacromonte a través de sus grabados (Granada: IDEAL y Fundación Abadía del Sacromonte, 2016), 62; Martínez Medina, Cristianos y musulmanes, 406-407.

42. Según la tradición los varones apostólicos son los discípulos de Santiago que fueron designados por san Pedro y san Pablo para evangelizar Hispania. Se tratan de Torcuato, Tesifón, Indalecio, Segundo, Eufrasio, Cecilio e Hiscio. Manuel Sotomayor, "Los fundamentos histórico-eclesiásticos del Sacromonte: de Santiago y sus varones apostólicos a los hallazgos de Valparaíso," en ¿La historia inventada? Los libros plúmbeos y el legado sacromontano, eds. Manuel Barrios Aguilera y Mercedes García-Arenal (Granada: Universidad de Granada, 2008), 32.

43. La Inmaculada de Raxis más conocida de la abadía del Sacro Monte ocupaba tradicionalmente las "Salas Capitulares"y hoy se emplaza en el plan de coro. Fue remozada en el siglo XVIII por Sánchez Saravia.

44. Las inscripciones árabes son coincidentes con unas presentes en el informe de Aradillas a continuación de la descripción presentada. El estudio de este lienzo, en paralelo con la leyenda, ha sido tratado por José Cárdenas Bunsen, La aparición de los libros plúmbeos y los modos de escribir la historia (Madrid: Iberoamericana-Vervuert, 2018). 


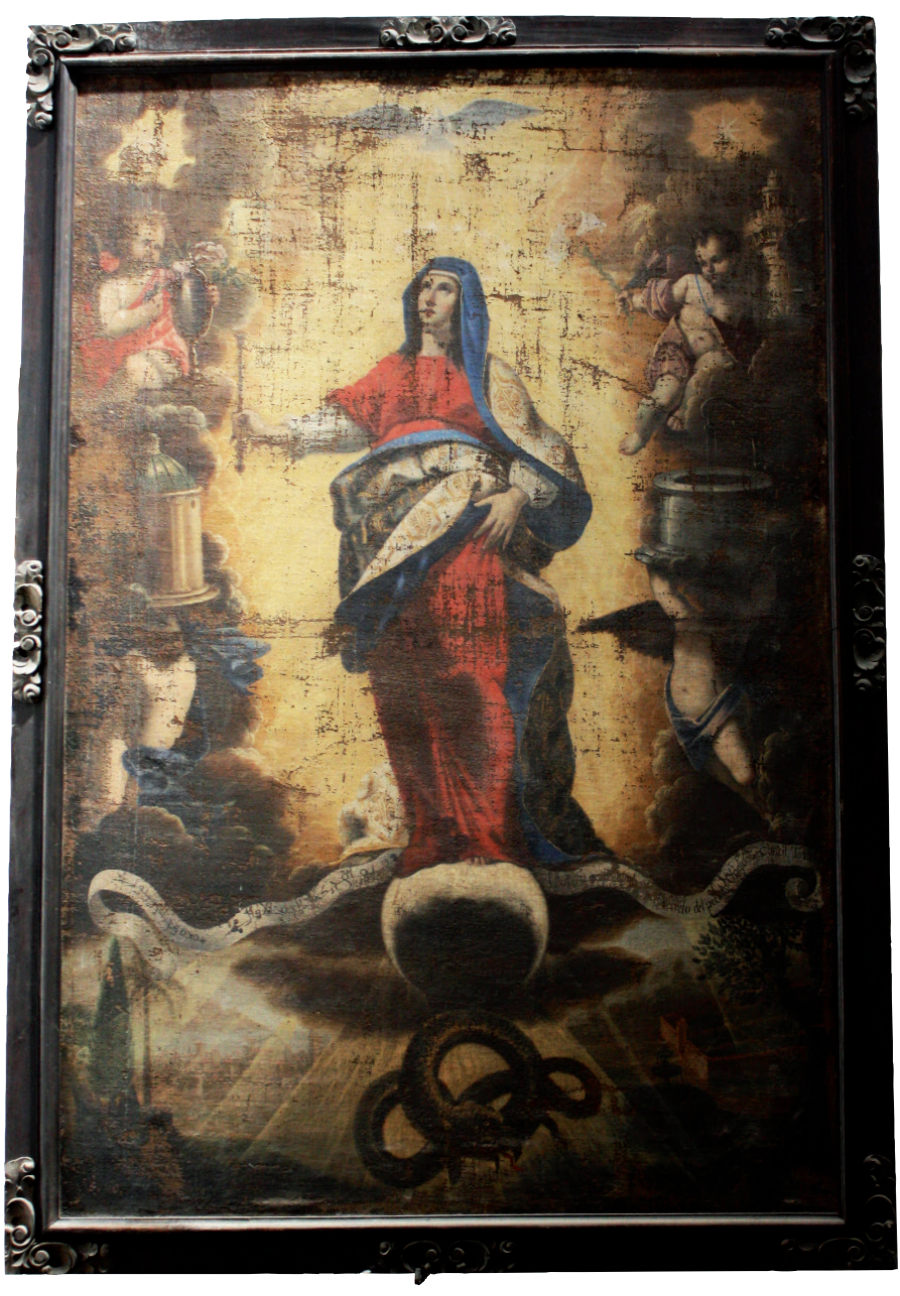

Fig. 4. Pedro de Raxis (atribución), Inmaculada Concepción, primera mitad del siglo XVII. Óleo sobre lienzo. Escalera principal de la abadía del Sacro Monte, Granada. esculturas, decora parte del manto, dibujando estrellas y motivos vegetales. El epitafio árabe y castellano, no estaba solamente en el cuadro, dado que, "en la puerta del oriente que mira a las santas cabernas, en el friso de la portada sobre el dintel de la puerta están cavadas en la piedra i doradas estas letras árabes i que en un frontal bordado que está en el altar de la limpia Concepción, en la Cueva de san Cecilio, están bordada de oro las mismas letras". La última de las inscripciones, realizada en este mismo periodo, con la intervención del propio Raxis, se conserva en la actualidad. Así pues, la plasmación, en arquitectura y pintura de estas leyendas, refuerzan el deseo del arzobispo Pedro de Castro de privilegiar a la Inmaculada Concepción. Su origen se halla en la

fracción del libro plúmbeo Fundamentum ecclesiae, donde se afirmaba que Jesús se había formado sin padre y alegaba que a María no le había tocado el pecado original. No olvidemos que el nacimiento de María, sin mancha de pecado, era un asunto coincidente y no contradictorio con el islam. Para confirmar este mensaje, Pedro de Castro llevó a cabo un intenso estudio y formuló varias formas de traducción. Asimismo el lema de "A María no Tocó el Pecado Primero", que pronto fue emblema de la abadía y del propio Castro, según los plúmbeos, lo confesaron los apóstoles como verdad católica en un concilio celebrado en Éfeso ${ }^{45}$.

La última mutación de la estética de los primitivos retablos fue a comienzos del XVIII, en que se le hicieron unos frontales de jaspe, siendo tesorero el canónigo Juan Riscos. En las cuentas del 1702 queda expresado el discargo de 840 reales y 28 maravedís pagados al maestro de cantería, Manuel Delgado, con los que, unidos a los 451 reales dados

45. Cárdenas Bunsen, La aparición, 96; Martínez Medina, Cristianos y musulmanes, 341-345. 
por Juan Delgado y Juan Ramírez, se completó la suma de 1.292 reales que costaron los dos frontales, "que se fuese cobrando de los restos de colexiales" ${ }^{\prime \prime 6}$. En cuanto a los capitulares, Delgado fue el canónigo obrero que estuvo al cuidado de la hacienda del Sacro Monte durante estos años y permaneció en la abadía entre 1688 y $1721^{47}$. De Juan Ramírez Castroviejo nos consta que fue canónigo desde 1695. Muy estimado y consultado por renombrados prelados, como el arzobispo Ascargorta y el cardenal Belluga. El primero le pidió asesoramiento para la gestión de su arzobispado. Finalmente, el obispo de Jaén, Rodrigo Marín, lo llamó para ser director del colegio-seminario de Baeza y de la congregación de San Felipe Neri de aquella ciudad. Falleció en Baeza en 171748. De estos frontales hoy no tenemos constancia y quizás fuesen vendidos para afrontar las obras en las que años después se implicó la abadía y para las que, como vamos a comprobar, estuvo especialmente necesitada de fondos.

\section{Dieciochescos}

La hechura y bendición de dos nuevos retablos colaterales está ligada a la ampliación del templo del verano de 1763. Se encuentran en el transepto de la iglesia colegial, ocupando el lado del evangelio, el de la Inmaculada, y el de la epístola, el de san José. Vinieron a sustituir definitivamente a los primitivos. Los retablos fueron obra de Francisco de Paula Castillo ${ }^{49}$ y las imágenes que los presiden del granadino Pedro Tomás Valero ${ }^{50}$. Para costearlos se dispensaron distintas donaciones de los capitulares, junto a raciones de comida y hogazas de pan $^{51}$. La primera noticia que tenemos de ellos corresponde al cabildo de 1 de junio de 1763, en que el canónigo Juan Rodríguez de Aragón denunció su necesidad. Ante la falta de fondos solicitó respaldo económico para el proyecto, a la par que ofreció 300 reales para dar inicio al del sagrario. Esta obra fue secundada

46. Cuentas 1697, legajo 90, Archivo Abadía del Sacro Monte (AAS), Granada.

47. Libro de Abades y Canónigos, 82v.

48. Libro de Abades y Canónigos, 258v.

49. Royo Campos, Abades, 157; Gallego y Burín, El Barroco, 116 y 253.

50. Royo Campos, Abades, 157; Gallego y Burín, El Barroco, 116. Pedro Tomás Valero fue un discípulo de Agustín Vera Moreno. Cuenta con atribuciones en la basílica de Nuestra Señora de las Angustias de Granada (retablo mayor) y el Sagrario. Es especialmente significativa su actividad en el camarín de la Virgen del Rosario de Santo Domingo. Encarnación Isla Mingorance, Camarín y retablo de Nuestra Señora del Rosario (Granada, 1990), 42-43; Ana María Gómez Román, "Torcuato Ruiz del Peral y el devenir de la escultura en Granada hasta mediados del siglo XIX," Boletín del Centro Pedro Suárez, no. 21 (2008): 354-357; Juan Jesús López-Guadalupe Muñoz, "Escultura y escultores en Granada en la época de Ruiz del Peral. Modelos, talleres y síntesis evolutiva," Boletín del Centro Pedro Suárez, no. 21 (2008): 312.

51. Este llamativo pago fue evocado en relación a la gratificación dada a fray Pedro del Santísimo Sacramento por afinar el órgano. Mercedes Castillo Ferreira, "Música y ceremonia en la Abadía del Sacromonte de Granada (siglos XVII-XIX)" (tesis doctoral, Universidad de Granada, 2009), 175 y 550, consultado el 15 de mayo de 2020, https://dialnet.unirioja.es/servlet/tesis?codigo=65588 
por el resto de capitulares, quienes aportaron la misma cantidad, a excepción del abad Martín Vázquez de Figueroa, que se comprometió a dar el doble. Se nombraron como comisarios a los canónigos López Chinchilla junto al susodicho Rodríguez de Aragón, "que harán ver a los señores los diseños de los tallistas para que se elija el más primoroso y acomodado al sitio"52. Esta operación fue resuelta poco después, como se deduce en el cabildo de 8 de julio: "vltimamente se expusieron y vieron los diseños que han dado los tallistas que solicitan hacer los dos retablos colaterales y también se remitió a la junta llamar ynteligente, desinteresado y escoger el más a propósito y ajustarlo"53. Finalmente se aprobaron y se les dio inicio en el cabildo de 22 de agosto ${ }^{54}$.

Sin embargo, la escasez económica, seguramente provocada por los gastos derivados de la defensa de los libros plúmbeos y de la ampliación de los estudios del colegio, hizo que los pagos se demorasen más de lo deseado. Ante esta situación, Pedro Valero tuvo una actitud muy complaciente con los canónigos, lo que no se puede decir del "maestro de tallista". Esto es patente en un memorial de Francisco de Paula, leído en cabildo de 1 de julio de 1765, "en que hace presente los perjuicios que le resultan, así a los dos retablos colaterales que tiene principiados tres años ha, que se lo mandaron algunos señores, cómo a él mismo, que tiene gastados muchos más reales que los que se le dieron para comenzar dicha obra. Que puede continuarse en el presente oportuno tiempo del verano, si el cauildo adaptase medio de darle algunos socorros para continuar su trabajo" ${ }^{\prime \prime 5}$. Ante ello, se acordó que se le dispensasen las dos hogazas y raciones diarias, que más de un año antes se habían dado a Pedro Valero. Aumentándose esta suma, con "los ciento y cinquenta ducados que dejó por su testamento el señor Sánchez para que se gastasen o distribuiesen a aduitrio y disposición del cauildo"56. Finalmente, nos consta que el abad Martín Vázquez de Figueroa se implicó directamente en el dorado del retablo de la Inmaculada, en agosto de $1770^{57}$. Esto suscitó el deseo de imitación de los canónigos que se "ofrecieron voluntariamente, según su posibilidad, para darle el mismo adorno al del otro lado, en el que está colocada la imagen del Patriarca señor

52. Además de los citados, asistieron al cabildo José Joaquín de Molina, Miguel Álvarez Cortés, Francisco Rico, José Montero y el secretario Manuel López de Mesa, al que se le encargó "lo noticie a los señores ausentes para que contribuían si gustasen a esta piados obra." Actas Capitulares 10, 1763-06-1, 217v, leg. 261, Archivo Abadía del Sacro Monte (AAS), Granada.

53. Actas Capitulares 10, 1763-07-08, 221r.

54. Actas Capitulares 10, 1763-08-22, 223v; José Antonio Peinado Guzmán, “El Sacro Monte como institución inmaculista granadina en los siglos XVII y XVIII," Revista del CEHGR, no. 25 (2013): 194.

55. Actas Capitulares 10, 1765-07-01, 295r. Lo relativo a Pedro Valero fue publicado en: José Antonio Peinado Guzmán e Isaac Palomino Ruiz, "Piezas inéditas de la Abadía del Sacro Monte en Granada," Ucoarte. Revista de Teoría e Historia del Arte, no. 3 (2014): 69.

56. Se esperaba que las finalizase antes del invierno. Actas Capitulares 10, 1765-07-01.

57. Recordemos que este asunto no es baladí, ya que en ocasiones superaba en costo al del propio retablo. Libro de Abades y Canónigos, 20r-v, publicado por Peinado Guzmán, El Sacro Monte, 196. 
san Joseph"58. Con ello ponían fin al proyecto de los retablos colaterales de la misma manera que se había iniciado, y se daban por concluidas las obras de ampliación del templo siete años después de su inicio.

Nos encontramos ante dos retablos "gemelos", de gran riqueza y suntuosidad barroca. De composición achaflanada, están constituidos por un solo cuerpo principal, rematado por un ático. Se estructuran por columnas compuestas acanaladas, sobre las que descansa un entablamento clásico. Las mismas reposan en unos sobresalientes basamentos que enmarcan el sagrario. En el caso del retablo de la Inmaculada, dicho sagrario está ornamentado por un cáliz en relieve con la Eucaristía. En el de san José, aparece una corona de laurel circundada por dos palmas de martirio (Fig.5). Así pues, en ellos es más que visible la decoración dieciochesca, con abundancia de roca-

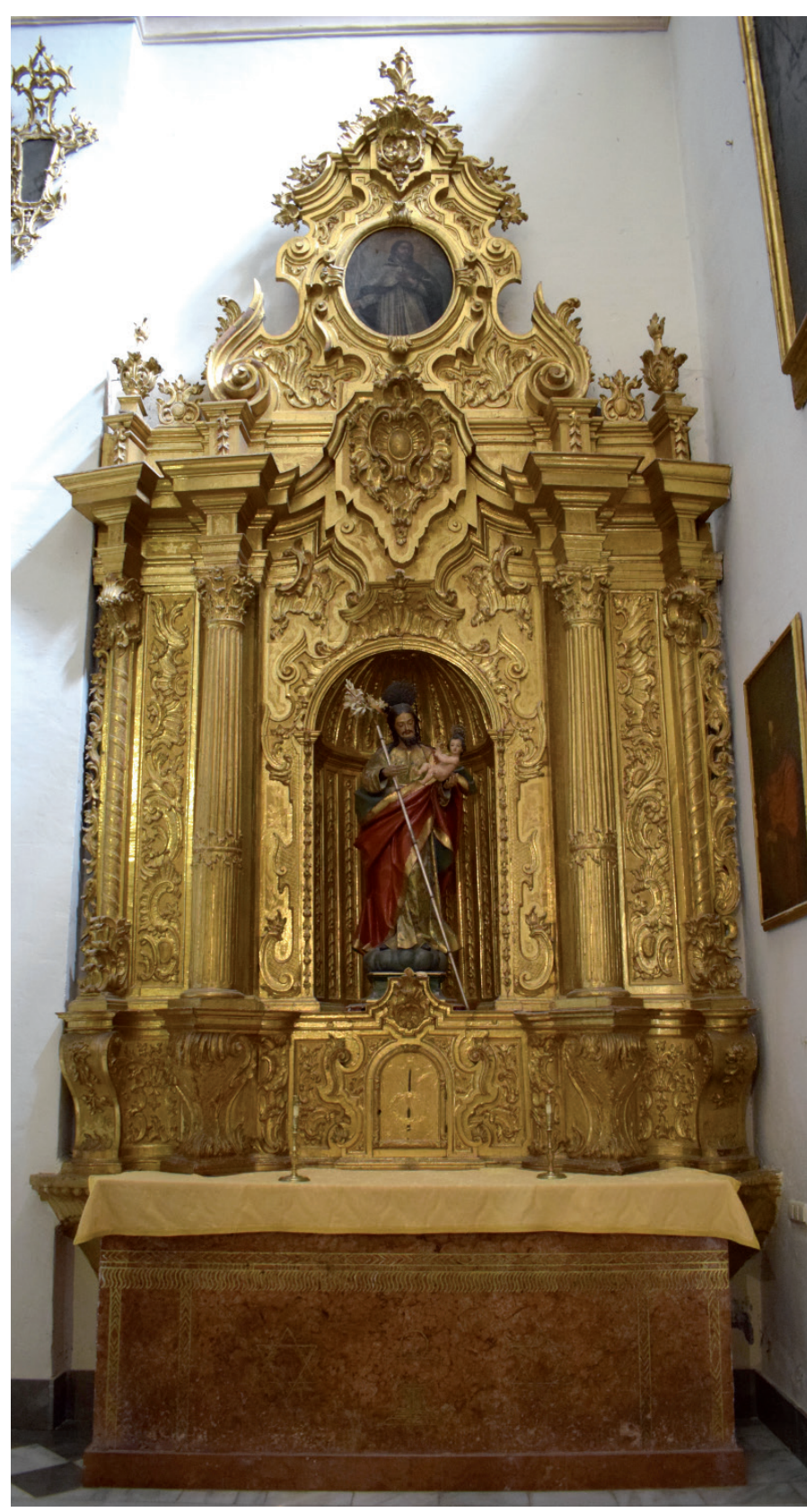

Fig. 5. Francisco de Paula Castillo, Retablo de San José, 1763-1770. Abadía del Sacro Monte, Granada. Ila. Ambos tienen en su ático lienzos enmarcados, en forma de tondo. En el retablo de la Inmaculada se representa al Niño Jesús, Salvador del Mundo, en la línea de la pintura devocional granadina del siglo XVIII59. Sedente, sobre un rompimiento celeste, se abre el pecho del que late un corazón flameante, mientras porta como atributo principal una cruz, la cual tiene enroscada

58. Actas Capitulares 11, 1770-08-06, 142r, legajo 262, Archivo Abadía del Sacro Monte (AAS), Granada. Citado en Royo Campos, Abades, 159. Asistieron Antonio López Chinchilla, Juan de Aragón, José Moreno, Manuel de Mesa, Miguel Álvarez, Francisco Rico, Julián de Villavicencio y Celdón de Salazar. Era presidente el antiguo colegial del Sacro Monte y rector del colegio, Andrés Mendiola. Véase: Manuel Barrios Aguilera, La invención de los libros plúmbeos. Fraude, historia y mito (Granada: Universidad de Granada, 2011), 407-411; Manuel Barrios Aguilera, Los falsos cronicones contra la historia (Granada: Universidad de Granada, 2004), 178-179.

59. Este tipo de representaciones fueron muy difundidas por el considerado como el principal discípulo de José Risueño: Domingo Chavarito. Gallego y Burín, El Barroco, 105. 
una corona de espinas. Este figura sobre un óvalo rodeado de rocalla y resaltado por molduras, con el Ave María. Por otro lado, en el remate del retablo de san José aparece san Juan Nepomuceno vestido de canónigo y con su estelaria. Asimismo, en su sotabanco, ambos altares están conformados por frontales marmóreos, probablemente incorporados en las reformas del siglo XIX. EI de la Inmaculada está constituido por una fina placa de mármol rojo y presenta, grabados en oro, dos sigilos de Salomón en sus laterales, y en el centro el Ave María coronado. Está flanqueado por unas incisiones también doradas, con distintos dibujos simulando flecos y grecas. En el caso de san José, podemos decir que se repite el modelo anterior, mudando el símbolo mariano por un cáliz coronado por la sagrada forma.

Por último, en cuanto a las imágenes que los presiden, conviene apuntar que la Inmaculada proyectaba en escultura el altar privilegiado de época fundacional ${ }^{60}$. Su hechura tenemos que vincularla con la nueva exaltación a su devoción dada en estos años por los descubrimientos de la alcazaba del Albaicín, como se ha visto ut supra. En ella es evidente la herencia de Cano, estando vestida por una túnica decorada por un rico estofado con suntuosas flores de corte orientalizante, algo propio en la moda de la épo$\mathrm{ca}^{61}$. En lo que respecta a san José, santo favorecido por los borbones, fue muy seguido en el Sacro Monte en el siglo XVIII, entre otros, por Tomás José de Montes, abad entre 1704 y 1715. No obstante, fue objeto de revisión. Así, por ejemplo, en el año 1760, el cabildo recibió del convento de San Antonio Abad el encargo de dar la debida censura a un libro apologético del patriarca que había recibido el colegio del Sacro Monte ${ }^{62}$. A pesar de ello la imagen contó con gran devoción como prueba su rico ajuar, constituido, además de otros objetos, por "potencias de plata"63.

\section{Retablo mayor}

El retablo primitivo era un panegírico de los libros plúmbeos. A propósito de su iconografía pudo estar influida directamente por el Libro de la naturaleza del ángel64. Es muy probable que su diseño fuese del propio Ambrosio de Vico, dada su trayectoria, y por

60. La corona de plata de la Virgen está registrada en: Inventario, 1817, leg.195, Archivo Abadía del Sacro Monte (AAS), Granada.

61. La "Casa Ajsaris" de Granada conserva entre su colección una Inmaculada de pequeñas dimensiones que está muy en la línea de la talla de la abadía, por lo que no sería descabellado atribuirla al mismo Valero. Si bien, ambas presentan algunas disonancias, especialmente palpables en la expresión del rostro, algo más suave que en la sacromontana, y en el movimiento y disposición del manto. 62. Libro de Abades y Canónigos, 17v.

63. Inventario, 1817.

64. Miguel José Hagerty, Los libros plúmbeos del Sacromonte (Granada: Comares, 2007). 
haber sido el arquitecto principal de la primera época de la abadía ${ }^{65}$. No cabe duda de que también debió intervenir Miguel Cano, cuanto menos en su ensamblaje. En él la Virgen, rodeada de una corte de ángeles músicos y en distintas actitudes, en varias pinturas (Anunciación, Nacimiento de Jesús y Asunción), y los mártires, representados por las reliquias y las esculturas de Santiago, san Patricio, san Cecilio y san Tesifón, fueron los grandes protagonistas, apareciendo también pintadas la Crucifixión, la Trinidad, junto a ángeles y serafines. Inmersos en el ambiente reivindicativo surgido en el siglo XVIII, en el contexto de los Defensorios, fue sustituido en 1746 por un retablo de escultura. Se ha podido documentar su conjunto escultórico como obra del granadino Domingo Cabrera, y fue donado por el antiguo colegial y beneficiado de la Virgen de la Angustias, Gregorio Eugenio de Espínola ${ }^{66}$.

\section{Primigenio}

Conocemos el antiguo retablo mayor por el cabildo de 23 de abril de 1746, donde, acerca de la discusión del programa iconográfico del que vendría a sustituirle, se nos brinda su valiosa descripción ${ }^{67}$. Era "un medio sexágono", organizado en un banco, dos pisos y tres calles (planicies), estructuradas por dos columnas (probablemente pares de ellas), culminadas en otras dos. Combinaba pintura y escultura. Este fue el tipo más recurrente del manierismo granadino, el cual (heredero en cierto modo del modelo escurialense) sería muy difundido a través de los diseños de Ambrosio de Vico, con la participación de Miguel Cano, como dan prueba, entre otros, los antiguos retablos de Santa Ana, San Cecilio y el de la parroquial de Albolote. Así pues, en su forma (medio hexágono) debía corresponderse con el de San Ildefonso, hoy en un lateral ${ }^{68}$.

Tenía en la calle central, sobre la mesa de altar y a ambos lados del sagrario, cubierto por un Ecce Homo de medio relieve, "dos relicarios donde se encierran varias reliquias de los santos mártires, inclusas en ricas custodias de plata y metal (...) el del lado del

65. José Manuel Gómez-Moreno Calera, La arquitectura religiosa granadina en la crisis del Renacimiento (1560-1650)(Granada: Universidad, 1989), 252-265.

66. Véase: José María Valverde Tercedor, “El retablo mayor de la Abadía del Sacro Monte de Granada y su conjunto escultórico de Domingo Cabrera (1746-1748). Datación, documentación y contextualización histórica," Anales del Instituto de Investigaciones Estéticas, no. 116 (2020): 93-128.

67. Las citas de este epígrafe corresponden a: Actas Capitulares 8, 1746-04-23, 435r-436v, leg. 261, Archivo Abadía del Sacro Monte (AAS), Granada.

68. José Manuel Gómez-Moreno Calera, "Evolución de la retablística granadina entre los siglos XVI y XVII," en La escultura del primer naturalismo en Andalucía e Hispanoamérica (1580-1625), ed. Lázaro Gila Medina (Madrid: Arco Libros, 2010), 257-264. 
evangelio está cubierto con una efigie de señor Santiago en traje de peregrino, con túnica, esclabina y sombrero pendiente a la espalda". Ostentaba uno de los libros plúmbeos abierto, "con las ojas orbiculares, que significa el de la certificación del Evangelio glorioso, que trajo el santo a este Sacro Monte, copia del que quedó enterrado en Jerusalén". El del lado de la epístola estaba decorado por otro medio relieve que, "por su antigüedad y carezer de rótulo se dudó si sería solo figura alegórica, que denotava el descubrimiento de las reliquias de la torre Turpiana, pero al fin, por sus circunstancias se conoció ser señor san Patricio, mártir del Sacro Monte, quien hizo el depósito de las mencionadas reliquias". En cuanto a su indumentaria, estaba compuesta por "su traje a lo español antiguo, con balona corta, ropilla, capa corta y calzones marineros". En su mano izquierda portaba una bandeja, "sobre la qual manifiesta un rótulo de plomo o ierro, mal embuelto y arrollado y una caja de la hechura de aquella en que se hallaron las reliquias de la torre Turpiana y encima de ella una tabla con escaques o ajedrezada, que indica una de las escripturas de señor san Zecilio halladas en dicha caja". A continuación, identifica, sobre ellos, dos óvalos grandes con inscripciones latinas grabadas en letras de oro sobre fondo negro que hacen referencia a los mártires del Sacro Monte y actualmente se conservan como parte integrante del retablo nuevo. "En una grande arca de piedra embebida entre la pared y el retablo, en la que se contienen las reliquias de los doze santos mártires". Seguidamente, en su segundo piso, "sostenida de una pequeña cornisa, se lebanta una pintura grande de la Asunción de Nuestra Señora, rodeada de ángeles con varios instrumentos músicos". Más adelante identifica sobre dicha pintura "otra más pequeña de un crucifijo en el plano que forma el sexabo". La Asunción seguramente sea la atribuida a Juan Sánchez Cotán que se conserva en una de las salas de visitas. Es una delicada pintura, en la que ángeles y querubines, en distintas actitudes, rinden pleitesía a la Virgen María. Además de los músicos, destacan los que la impulsan primorosamente, situados a sus plantas. También son dignos de mención dos situados sobre ella, en actitud de imponerle una rica corona de imperios estrellados ${ }^{69}$.

En las calles laterales, en el lado del evangelio, reconoce un nuevo relicario destinado a las láminas sepulcrales y a los libros plúmbeos, que recordemos que en el momento de la descripción se hallaban en Roma. Se encontraba sobre una pilastra fingida (pintada) y estaba cerrado por una reja dorada de dos puertas, con cuatro llaves, tres candados y una cerradura en la puerta interior de madera, "en la que se lee el siguiente epígrafe:

69. Martínez Medina, Cristianos y musulmanes, 386; José Manuel Pita Andrade, Museo del Sacro Monte, vol. 20 de Guías de los Museos de España (Granada: Ministerio de Educación Nacional, Dirección General de Bellas Artes, 1964), 20. 
Gloriam regni tui dicent, et potentiam tuam loquentur, ut notam faciant filiis hominum potentiam et gloriam magnificentiae regni tui. Ps. $144^{\prime \prime 70}$. Sobre él se emplazaba una de las dos esculturas de bulto redondo que formaban el retablo71. Concretamente, "san Zezilio vestido de pontifical, en una mano el báculo y en la otra un libro de plomo de figura orbicular abierto"72. Era coronado por una pintura de la Anunciación. Dada la iconografía del retablo y el protagonismo de los ángeles, podría tratarse de la representación que se conserva en una de las estancias de visitas del complejo sacromontano, en la que María recibe la corona de reina de los ángeles. Pintura de comienzos del siglo XVII de gran originalidad iconográfica. Está ambientada en el interior de una estancia, definida por el suelo ajedrezado y el cortinaje barroco que se abre en un lateral. La misma es cubierta por un rompimiento celeste del que surge el ángel, en actitud orante. Este personaje se encuentra en el momento de bendecir a la Madre de Jesús con su mano derecha, mientras con la izquierda le entrega una corona real, apareciendo entre ambos la inscripción de Regina angelorum.

Seguidamente, en el lado de la epístola había una nueva alacena, sobre una pilastra fingida. En este caso estaba cerrado por una reja dorada con dos llaves correspondientes a ella y a la puerta de madera interna, con la inscripción de "Sancti in solitudinibus errantes, in montibus et Espeluncis et in cabernis terrae: tanquam aurum in fornaze Deus probavit illos, et quasi holocausti hostiam accepit illos ${ }^{\prime \prime 3}$. Estuvo dedicada a algunos relicarios "de madera preciosa con christales que encierran reliquias de los santos mártires, así de las cenizas como de las masas de piedra, cal y un relicario triangular en forma de pirámide, con la canilla de señor san Mesitón"74. Encima, en correspondencia con el nicho de san Cecilio, "está colocada la efigie de señor san Thesifón de estatura entera, también de Pontifical, y en una mano un libro de plomo abierto (...). Sobre este nicho hai otra pintura del Nacimiento de Nuestro Señor Jesuchristo". Por su composición y temática, probablemente sea el Nacimiento atribuido al pintor florentino asentado en Madrid, Vicente Carducho (1576-1638), y datado en 163175. Está conformado por

70. "Hablarán de la gloria de tu reino y anunciarán tu poderío, para que los hijos de los hombres conozcan tu poder y la grandeza de tu reino." Es la gloria que Dios, en sí mismo, mandó a los apóstoles. Miguel Ángel Almenara, Pensamientos literales y morales (Valencia: Juan Crisóstomo, 1623), 348.

71. Fueron enviadas a la localidad granadina de Deifontes.

72. Ha sido citado en Martínez Medina, Cristianos y musulmanes, 261.

73. "Unos santos que andaban errantes por las soledades, los montes, las cuevas y las cavernas de la tierra. Dios los probó como al oro en el horno y los recibió como víctimas de holocausto." Libro de la Sabiduría 3,6. Según Jesús María Morata está estrechamente relacionada con la inscripción de esta misma época que ostenta en piedra la fachada de las Santas Cuevas.

74. Este relicario se conserva en una de las alacenas del retablo mayor actual.

75. Antonio Gallego y Burín, Granada, Guía artística e histórica de la ciudad (Granada: Comares, 1996), 365. Posteriormente fue situado en el plan del coro, lugar que hoy ocupa. Inventario, 1951-1955, 65, Fondo Abadía, Archivo Abadía del Sacro Monte (AAS), Granada. 
un conjunto de ángeles músicos, los cuales acompañan la escena y coronan un rompimiento celeste. Este cuadro se conserva en el plan de coro ${ }^{76}$. Sin embargo, nos consta que en el Setecientos recibió culto en un altar en la iglesia, como testimonia el cabildo de 1 de junio de $1707^{77}$. Por último, culminaba el retablo "una cornisa igual, que por serlo deja descubierto el medio punto del arco del altar maior, en cuia bóbeda en un obalo grande en medio hai una pintura al óleo de la Santísima Trinidad". Le acompañaban ángeles y serafines distribuidos por toda la bóveda en pequeños óvalos, "de los quales sobresalen dos, ia por maiores que los demás, ia por lo apreciable de su pintura mui antigua (...) y en ellos se ven dos choros de ángeles grandes con varios instrumentos y papeles músicos".

Antes de hacer un nuevo retablo se intentó remozar o recuperar el antiguo, como se extrae en una libranza de 1 de noviembre de 1724, de 80 reales de vellón dada por el mayordomo de hacienda, Bartolomé Rodríguez y Quiñones, al pintor Diego de Hermosilla ${ }^{78}$, "para pagarle su trabajo de pintar las faltas del retablo de este Sacromonte que con esta libranza y sin otro recado se abonarán a vuestra merced en quenta de los siete mil reales"79. Las "faltas" pueden atribuirse a un eventual mal estado de conservación, aunque parece más acertado relacionarlas con las modificaciones que en el XVIII afectaron a la iconografía tradicional de la abadía.

\section{Dieciochesco}

Heredero del antiguo, el retablo mayor actual es un elocuente relicario. Atribuido a Blas Antonio Moreno, es una fábrica barroca, estructurada en tres calles por contundentes estípites. Su programa iconográfico responde a la idea de exaltar la abadía como martyria paleocristiano. Realizado por completo en escultura, exenta y en relieve, reproduce muchos temas del primitivo, sin embargo, en detrimento de otros, concede mayor protagonismo a los mártires (Fig.6). Por su predominio escultórico tan solo podría ser comparado en Granada con el mayor de San Ildefonso, donde trabajaron

76. En este lugar es localizado a mediados del siglo XX. Inventario, 1951-1955, 65.

77. Actas Capitulares 6, 1707-06-01, 274v. Archivo Abadía del Sacro Monte (AAS), Granada.

78. Es posible el parentesco de Diego de Hermosilla con José de Hermosilla y Sandoval, arquitecto de su misma época. En 1752 lo encontramos como director de arquitectura de la Real Academia de Bellas Artes de San Fernando, donde imprimió las Antigüedades Árabes de España. En el año de 1766 se le encomendó levantar plantas y alzados de la Alhambra, perfeccionando la obra de Diego Sánchez Saravia. Carlos Sambricio, "José de Hermosilla y el ideal historicista de la llustración," Goya, no. 159 (1980): 140-151; Delfín Rodríguez Ruiz, "De la utopía a la Academia. El tratado de arquitectura civil de José de Hermosilla," Fragmentos, no. 3 (1989): 58-80.

79. Libranza a Diego de Hermosilla, 1724, leg. 54, Archivo Abadía del Sacro Monte (AAS), Granada. 
Blas Moreno y José Risueño, siendo también destacable en este aspecto el de Nuestra Señora del Rosario de Santo Domingo, en el que igualmente actuó Moreno ${ }^{80}$.

Para su estudio es imprescindible la información dada en el cabildo de 23 de abril de 1746, en este caso, por la publicación de su proyecto ${ }^{81}$. En él se acordó, por la mayor parte del cabildo, que "ocupasen los dos nichos principales de los lados, que son los que caen sobre las dos rejas de láminas y reliquias señalados con el número 1, señor san Cecilio, al lado derecho y a el izquierdo señor san Thesifon, ambos de pontifical, con libros redondos de plomo en las manos". Por su parte, en dos nichos y sobre los dos relicarios altos que flanquean el manifestador, "se pusiese en el del lado derecho Santiago, en el regular traje de peregrino, con libro redondo de plomo en la mano, y en el del lado siniestro señor san Hiscio, vestido de Pontifical, sin libro". Por otro lado, en las puertecillas de los relicarios que acompañan el sagrario iría dispuesto, al lado derecho, "san Patricio en traje sacerdotal con una vandeja en la mano y en ella un rótulo de plomo arrollado y la caja de las reliquias de la torre Turpiana, en la forma que aora está en nuestro retablo antiguo". Apareciendo en el izquierdo "san Mesitón en traje de apóstol con cruz larga que le sirva de báculo". Asimismo, describe en los laterales cuatro medallones, dos pequeños bajo la cornisa principal y dos grandes sobre ella. En el

80. Juan Jesús López-Guadalupe Muñoz, “Del Barroco avanzado al Neoclasicismo en la retablística granadina del Setecientos. Apuntes para una monografía," Cuadernos de Arte, no. 29 (1998): 94-96.

81. Las citas subsiguientes corresponden a: Actas Capitulares 8, 1746-04-23, 436v-437r.

atrio Revista de Historia del Arte, no 26 (2020): 148 - 182

elSSN: 2659-5230. https://doi.org/10.46661/atrio.4933 
lado derecho, en los pequeños a "señor san Septentrio y en el izquierdo, en una misma medalla, los dos santos san Maximino y Lupario". Se encontrarían en las dos medallas grandes, en la del "lado derecho señor san Miguel, en la del izquierdo señor san Rafael". Seguidamente, sobre ellas aparecerían, "en la del lado derecho señor san Turilo, en la del izquierdo señor san Centulio (...) al lado derecho san Panuncio y al izquierdo san Maronio". Finalmente figuraría sobre el manifestador "san Gabriel, y en el nicho principal que haze centro del retablo la Asunción de Nuestra Señora, y en la medalla que haze clabe del arco la Santísima Trinidad".

Este proyecto fue seguido en la hechura del retablo casi en su plenitud y nos puede ayudar a aclarar muchas dudas sobre su iconografía. Entre los interrogantes desvelados se encuentra el situar a san Cecilio en una de las calles laterales, formando pareja con san Tesifón, y no en la central, junto a Santiago, como se ha creído. También nos confirma que ambos Ilevaron libros plúmbeos, eliminados a finales del siglo XVIII, y que los identificaban como sus autores. Recordemos que la forma más habitual de representar al patrón de Granada fue con dos círculos (plomos), decorados con las estrellas entrecruzadas que aparecieron grabadas en ellos ${ }^{82}$. Con su eliminación se simbolizaba el paso de la abadía de su controvertida tradición a la modernidad.

Por último, también sabemos que contó con ángeles lampadarios o lampareros. En cabildo de 7 de agosto de 1745, se aprobó la reubicación de las seis lámparas de plata que estaban emplazadas en los arcos del pavimento bajo, colocándose una de ellas en la capilla de Nuestra Señora del Rosario. De las otras cinco el tesorero debía ordenar fundirlas para la extracción de cuatro homogeneizadas, "para que, al tiempo de colocar el retablo se hagan quatro ángeles que las mantengan, y estén con más decencia, pudiéndose encender más a menudo, siruiendo así de maior culto y decencia"83. Tres ángeles, de los que se desconocía su procedencia, se han conservado durante años descontextualizados en una estancia de las crujías. Los mismos presentan un más que mejorable estado de conservación, y aunque parecen algo toscos, por sus características no cabe duda de que son los originales. Su postura, cargada de un movimiento, enfatizado por la posición de las rodillas (unas dobladas y otras estiradas) y de los brazos abiertos, como levitando, es la típica de estas esculturas. Ocurre lo mismo con la vestimenta, con túnica volada y botas. Este tipo de imágenes alcanzaron gran predicamento en el Setecientos, especialmente en Sevilla, donde abundan ejemplos de artistas tan reputados como

82. Martínez Medina, Cristianos y musulmanes, 261. 83. Actas capitulares 8, 1745-08-07, 408v. 
Roldán, Duque Cornejo, Hita del Castillo o Cayetano D'Acosta ${ }^{84}$. En el caso de Granada los más llamativos son los presentes en la basílica de San Juan de Dios, existiendo, entre otros templos, en el presbiterio de Santo Domingo ${ }^{85}$.

\section{Retablo de Nuestra Señora del Rosario}

De todos los retablos del XVIII el más antiguo fue el de la capilla de Nuestra Señora del Rosario, principal devoción de los colegiales y su patrona. Su hechura, ideada por el rector Antonio López Chinchilla, su comisario, en 1743, motivó unas obras de ampliación de dicho espacio, siendo abad Gaspar Salcedo (1743-1761)86. Con él la abadía revestía de magnitud el altar destinado a cobijar a la titular de la cofradía filial de la Archicofradía del Rosario, que desde sus inicios y por deseo de Pedro de Ávila, vino a paliar la Iontananza de los sacromontanos del templo de Santo Domingo.

\footnotetext{
Yten, propuso dicho señor rector, cómo del dinero que davan los comisarios de Nuestra Señora del Rosario, y de varias contribuciones y limosnas de diferentes particulares, tenía ajustado un retablo para la capilla del Rosario. Y que para este efecto era conveniente el que dicha capilla se ampliase, estendiéndose algunas varas por la parte de la placeta de las Quebas, para cuia obra tenía medios suficientes y solo necesitava la licen-/cia del cavildo, la que con efecto pedía. Lo que entendido se acordó conceder dicha licencia con la precapción de que no se llegase a romper la pared hasta tener asegurados los medios para costear la obra, ni tampoco, sin que quedase aquel sitio con el devido resguardo ${ }^{87}$.
}

Para las obras de la capilla, según recibo de 23 de abril de 1744, Gregorio de Espínola donó 150 reales, 20 maravedís de vellón, en calidad de antiguo colegial del Sacro Monte y miembro de la cofradía ${ }^{88}$. Sin embargo la contención decorativa del retablo, en armonía con la decoración clasicista de su capilla, deja en evidencia una posible transformación del mismo en el siglo XIX (Fig.7). En madera policromada, consta de un solo cuerpo y está estructurado en tres calles, presentando el frontal de mármol. La central, mayor que las laterales, custodia una hornacina con la patrona del colegio, atribuida a Pablo

84. Manuel Jesús Roldán, “Ángeles que dan luz," Pasión en Sevilla, ABC, julio de 2020, consultado el 17 de octubre de 2020, https://sevilla. abc.es/pasionensevilla/actualidad/noticias/angeles-dan-luz-los-grandes-acompanantes-los-retablos-180874-1595191019.html.

85. Sobre la cofradía, véase: José María Valverde Tercedor, "Cofradías y religiosidad popular en la Abadía del Sacro Monte," en III Simposio Internacional de Historia de Semana Santa de Granada (Granada, 22 de febrero de 2020), coords. Francisco Javier Crespo Muñoz y José María Valverde Tercedor (Granada: Nuevo Inicio, 2020), 79-122.

86. Fue planteada por vez primera en el cabildo de 8 de julio de 1743. Actas Capitulares 8, 1743-07-08, 343r-v; Libro de Abades y Canónigos, 285v.

87. Actas Capitulares 8, 1743-07-08, 343v-344r.

88. Limosna a la capilla de Nuestra Señora del Rosario, Patronato Espínola, leg. 13, Archivo Abadía del Sacro Monte (AAS), Granada. Citado en Isaac Palomino Ruiz, "Patrocinio y mecenazgo de Gregorio Eugenio de Espínola sobre templos granadinos," en El Barroco: Universo de Experiencias, eds. María del Amor Rodríguez Miranda y José Antonio Peinado Guzmán (Córdoba: Asociación Hurtado Izquierdo, 2017), 89. 


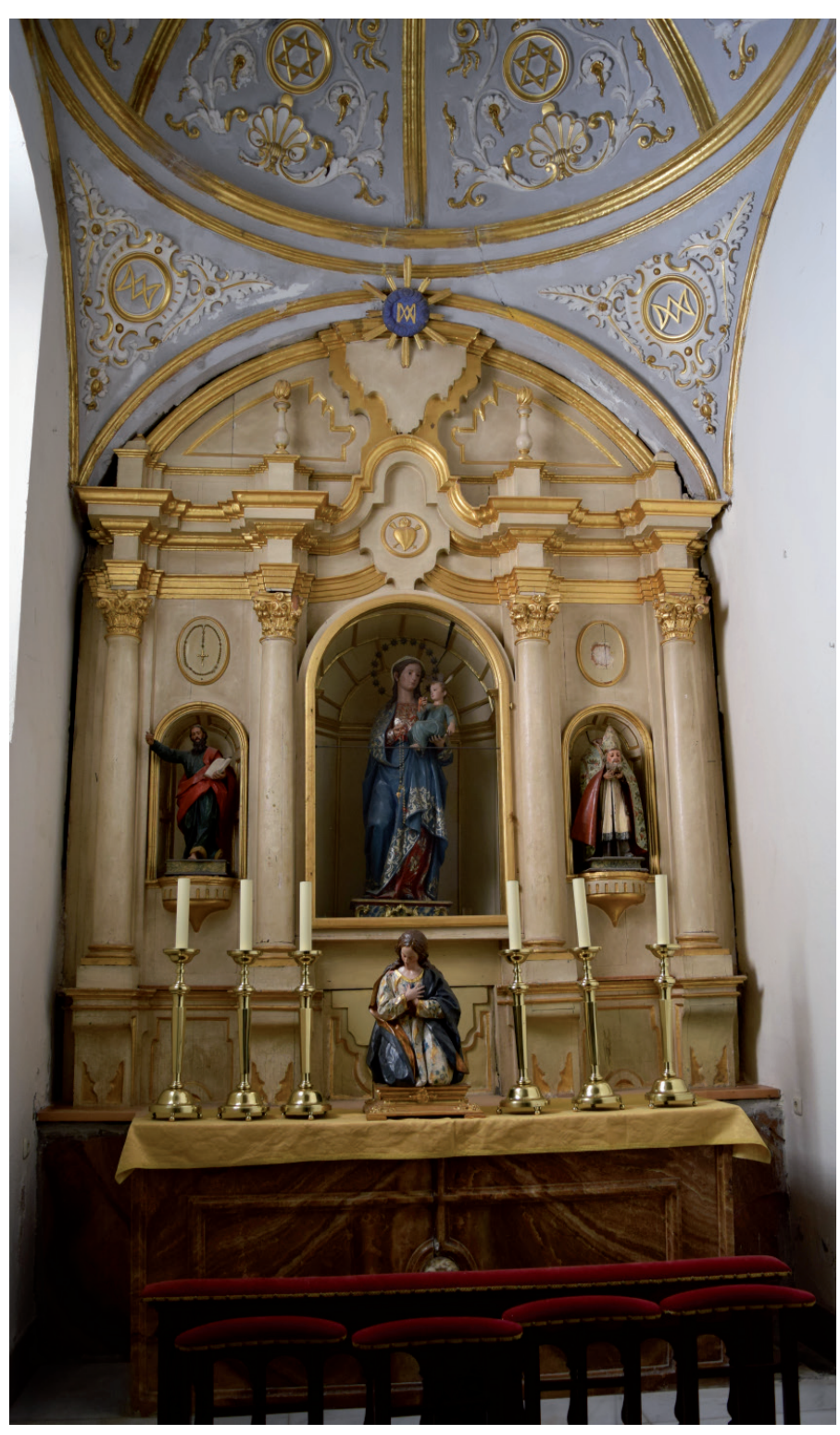

Fig. 7. Capilla y Retablo de Nuestra Señora del Rosario, 1744. Abadía del Sacro Monte, Granada. de Rojas y datada en 1599. Las laterales, con hornacinas menores, están dedicadas a san Pablo y a san Dionisio Areopagita, respectivamente ${ }^{89}$. Sobre ellas se desarrollan óvalos donde figuran rosarios incisos. Las calles del retablo están divididas por columnas compuestas sobre las que descansa el entablamento. La talla combina formas curvilíneas y mixtilíneas y está compuesta a base de placas recortadas. La calle central aparece decorada por un tondo con un corazón flameante, coronado por otro con ráfagas, en cuyo centro figura el Ave María. Está policromado en blanco, a excepción de los capiteles de las columnas, frisos y remates, dorados. La ampliación de la capilla fue finalizada en noviembre de 1744, como consta del cabildo de día 23, en que se dio licencia para su bendición, por el secretario del arzobispo Felipe de los Tueros y Huerta. "Se determinó que en el día siguiente

se ejecutase dicha celebridad con aquella solemnidad que en semejantes funciones se acostumbra"90. La capilla del Rosario tiene especial significación al estar conectada directamente con el panteón y capilla del fundador. Con esta obra se daba entidad arquitectónica a un espacio que fue muy favorecido por el primer abad electo del Sacro Monte, Pedro de Ávila y Herrera, y por el canónigo obrero, también de la fundación, Francisco de Barahona Miranda, quienes lo enriquecieron con importantes dádivas, algunas de ellas procedentes de Roma, como es el caso de dos lienzos del martirio de san Lorenzo, hoy en el plan de coro de la abadía.

89. Inventario, 1951-1955, 32.

90. Actas Capitulares 8, 1744-11-23, 386v. Citado en: Palomino Ruiz, "Patrocinio y mecenazgo," 89. 


\section{Retablo del Santo Cristo, de la capilla del fundador}

El retablo del Santo Cristo de la capilla del fundador fue realizado, al igual que los laterales, por el tallista Francisco de Paula del Castillo, según las cuentas de 1770, siendo tesorero Manuel López de Mesa. Con él culminaba su trabajo en la iglesia. "Item, de (trescientos reales que se gastaron en el altar y retablo de Santo Cristo) quando se colocó en la capilla del señor fundador. Los 240 reales que se dieron a Francisco de Paula, tallista por los días que travajó y los 60 reales restantes por las tablas, yeso, jornales de albañiles y otros gastos, que constan de la relación de dicho señor Mesa, que ha presentado y queda en esta contaduría con los recados de sus quentas...300"91. Costeó su dorado el canónigo Joaquín de Iparraguirre, quien fuera uno de los comisarios del retablo mayor, como se anunció en el cabildo del 3 de agosto de 1773. "Item, ofreciendo además el señor I parraguirre dorar a su costa el retablo del altar que está en la capilla donde se halla sepultado nuestro venerable fundador/ se admitió con especial complacencia dándole repetidas gracias por lo mucho que se esmera en beneficio desta santa casa"92.

Este retablo sigue la línea estética de los colaterales. No obstante sus proporciones, algo más discretas, denotan una clara adaptación al espacio, como demuestra la sustitución de las columnas monumentales por unos sencillos estípites. Su decoración más dominante es la rocalla. Asimismo, está circundado por una crestería, que remata un pronunciado guardapolvo y recuerda a la empleada en el XVIII como marco de los altares de las naves laterales del templo, al igual que su altar, con forma de ménsula. Por otro lado, su dedicación al Crucificado coincide con la iconografía de su ático, formado por un óvalo pictórico enmarcado con una Dolorosa (Fig. 8).

Constituye el colofón a las labores de reparación y ornato del panteón del fundador del Sacro Monte, llevadas a cabo desde 1739, por iniciativa del presidente del cabildo Diego Nicolás Heredia Barnuevo, con el fin de enaltecer la figura de Pedro de Castro. Actualmente está presidido por la figura de un arzobispo el cual, ataviado con casulla romana celeste, palio y mitra, porta un libro en su mano izquierda. Ha sido identificado como san Antonino de Florencia por ser en esta capilla el lugar donde estuvieron custodiadas las reliquias del dominico, donadas por el primer abad electo de la institución, Pedro de Ávila ${ }^{93}$. Sin embargo, parece más lógico relacionarlo con

91. Cuentas de 1771, leg. 30, Archivo Abadía del Sacro Monte (AAS), Granada.

92. Actas Capitulares 11, 1773-08-03, 223r-v.

93. En el inventario de los años 50 se reconoce en dicho espacio un Sagrado Corazón, lo que nos hace pensar que este retablo experimentó una reformulación en el siglo XIX. Inventario, 1951-1955, 30. 


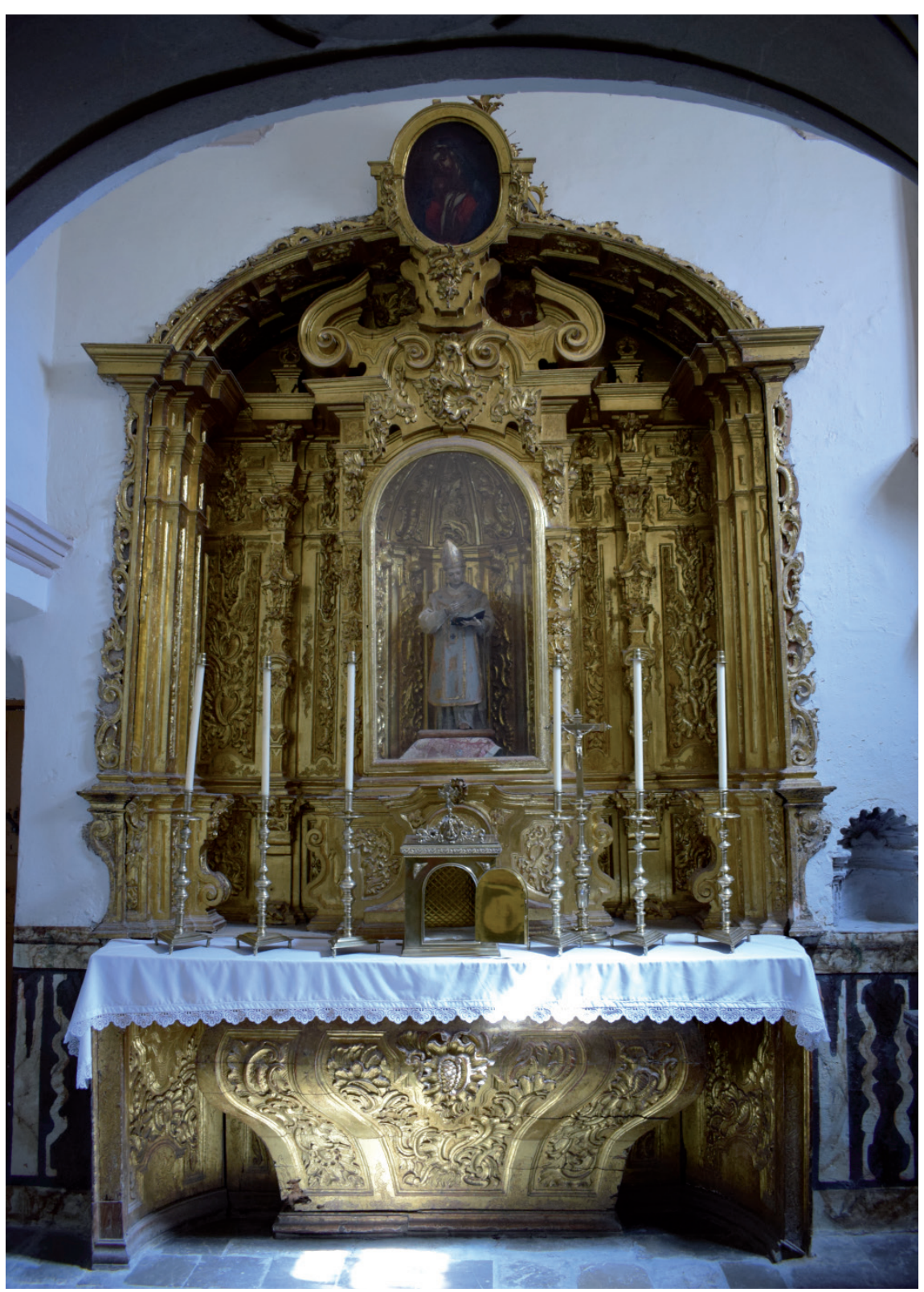

Fig. 8. Francisco de Paula Castillo, Retablo del Santo Cristo, 1770-1773. Abadía del Sacro Monte, Granada. san Cecilio como arzobispo de Granada ${ }^{94}$. Tengamos en cuenta que la imagen, de talla completa, y cuya concepción concuerda con el modelo estético extendido en Granada por Pablo de Rojas, es anterior al propio retablo, por lo que pudo proceder o bien del altar mayor primitivo o de alguno de los que conformaron las Santas Cuevas.

La dedicación al Santo Cristo y mártires comulga a la perfección con la función primitiva de este lugar, como capilla relicario, y es heredera del altar que Pedro de Ávila puso a un Crucificado, por él donado, en la iglesia ${ }^{95}$. No obstante, su estructura, presidido por una hornacina, parece más acorde para un Crucificado menor que para un Cristo de tamaño natural. Esta teoría coincide con la donación del canónigo de la catedral de Cádiz, Juan Domingo Lasquetty y Restán, en el año 1762, siendo abad Luis de Viana, de un Crucificado de marfil para la iglesia del Sacro Monte. Lasquetty era miembro de una de las familias nobles más importantes de Cádiz ${ }^{96}$ y es muy posible que heredase su vínculo con la abadía del sacromontano José de Barcia y Zambrano, obispo de Cádiz (1691-1695). Se dio a conocer en el cabildo de 15 de abril, "en que hizo relación el señor presidente de dos cartas que se presentaron de don Juan Lasqueti, sobre la donación que auía hecho al cabildo de vn crucifixo de marfil, mui precioso y estimable, para que se le diese culto en nuestra iglesia"97. El deseo inicial del donante era que estuviese en la "capilla y altar

\footnotetext{
94. Seguramente proceda de los altares primitivos de la iglesia o del complejo de las Santas Cuevas.

95. Testamento de Pedro de Ávila, 1651 (copia), leg. 1, Archivo Abadía del Sacro Monte (AAS), Granada.

96. Revista de historia y genealogía española (Madrid: Sucesores de Rivadeneyra, 1912), 1:29.

97. Actas Capitulares 10, 1762-04-15, 188v-189r.
} 
de Nuestra Señora del Rosario"98. Sin embargo, pronto aceptó la propuesta de algunos capitulares de emplazarlo en un altar separado. Según se dijo, Lasquetty, "conuenía gustoso en ello y se determinó se le haga vrna decente y se ponga en el altar donde está el quadro del Nacimiento [que fue objeto de varios movimientos en esta época] y que este se mude y ponga en el altar de enfrente, en lugar de el crucifixo grande"99. Así pues, para la recepción de dicha donación se otorgó comisión al presidente, Martín Vázquez de Figueroa, "que la admitió gustoso por su deuoción"100. Al mismo tiempo, el cabildo le encomendó al secretario Manuel López de Mesa, enviarle un agradecimiento mediante correspondencia, "por su apreciable dádiua"101. La abadía del Sacro Monte conserva varios crucificados de marfil, si bien ninguno de ellos parece encajar en la hornacina central del retablo, por ser todos de menores dimensiones. Los dos principales son el que se custodian en el Museo, conformando un Calvario con ciertos aires flamencos, junto a la Dolorosa y san Juan, y el que se halla presidiendo el manifestador del retablo mayor de la colegiata. Imagen manierista, muy expresiva, cuya corpórea anatomía adapta su contorsión al cuerno de marfil. Se alza sobre una cruz plana, con cantoneras en broce dorado con decoración vegetal. Plantea un canon muy clásico con evidente influjo italiano roto por el pathos de su rostro de abultada corona de espinas.

\section{Retablo de la capilla del reservado}

Este retablo fue donado por Martín Vázquez de Figueroa, conjuntamente con el adorno de la capilla que preside, emplazada al final de la escalera de la iglesia. Según se refiere el Libro de Abades y Canónigos, el abad "costeó el retablo y adorno de la capilla junto al coro"102. Conocida como capilla del Pilar o del reservado, ha sido también llamada del plan de coro o de enfermos ${ }^{103}$. Su último apodo se deriva de su situación estratégica, junto al espacio residencial de los canónigos. Esta intervención está vinculada a las operaciones de renovación y adaptación del espacio del antiguo pórtico, llevadas a cabo en 1763 y sostenidas desde un principio, al igual que en el templo, por el canónigo

98. Actas Capitulares 10.

99. Actas Capitulares 10. Debe referirse al crucifijo de las Misericordias. Libro de Abades y Canónigos, 2v.

100. Actas Capitulares 10, 1762-04-15, 188v-189r.

101. Actas Capitulares 10.

102. Libro de Abades y Canónigos, 20v.

103. Capilla del reservado es llamada en Zótico Royo Campos, Bellezas Sacromontanas (Granada: Anel, 1967), 68. Un inventario hace referencia a ella como la capilla de enfermos. Inventario, 1817. También fue conocida como capilla del señor san José y de Nuestra Señora del Pilar. Royo Campos, Abades, 160. 


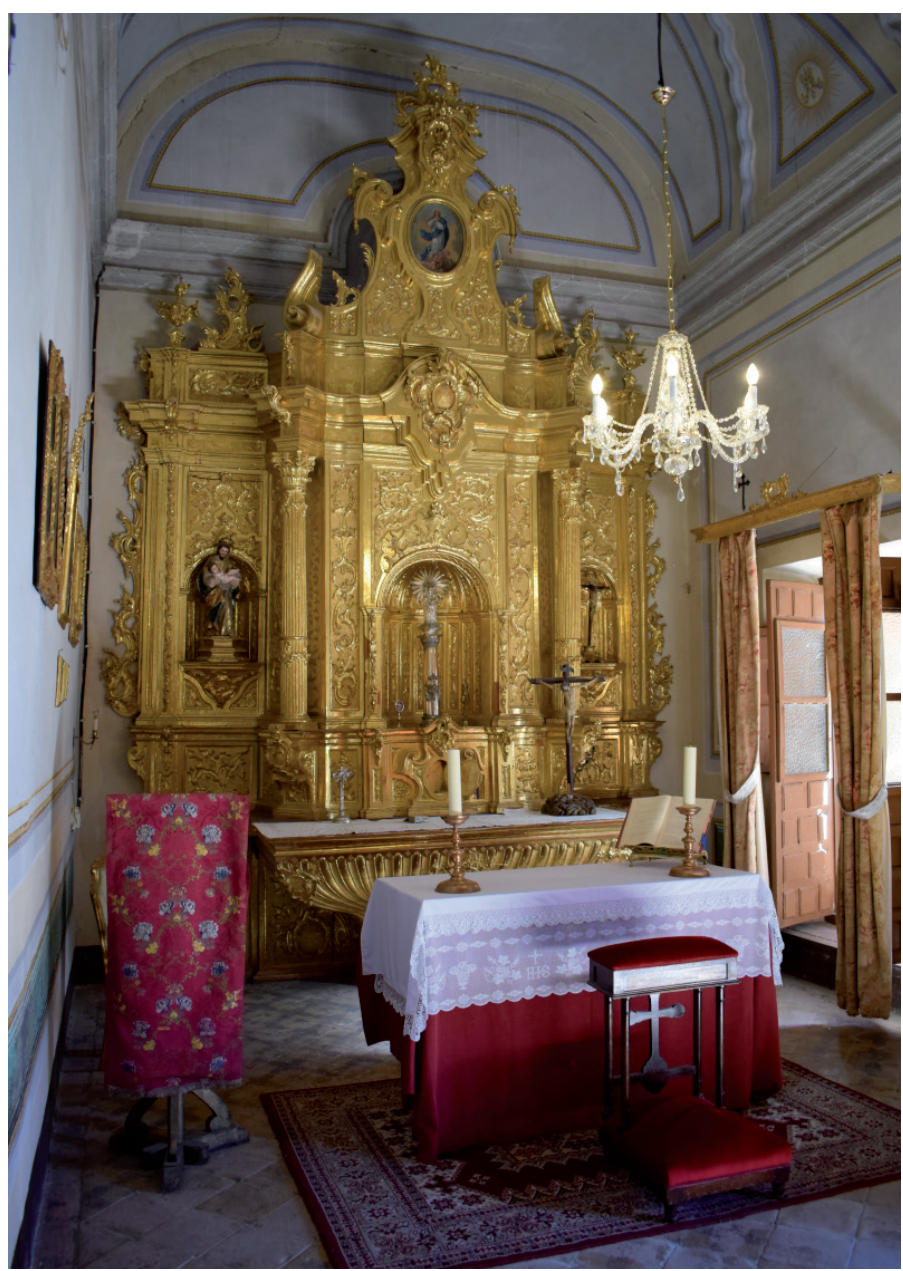

Fig. 9. Francisco de Paula Castillo (atribución), Retablo de la capilla del reservado, ¿1763? Abadía del Sacro Monte, Granada.
Manuel López de Mesa ${ }^{104}$. Las mismas concluyeron con la realización de una nueva escalera. La capilla y su primitiva escalera habían sido promovidas por el arzobispo Ascargorta, a comienzos de siglo, junto a una librería para servicio del coro ${ }^{105}$. Con respecto a su ornamentación, debió ser bastante primorosa. El inventario de 1817 reconoce en ella una serie de objetos: "vna ymagen del Pilar con corona de plata, vna ymagen de Santiago con diadema de plata, dos relicarios de plata en el sagrario del altar, vn crucifijo de madera con peana y trece quadros, entre grandes y pequeños ${ }^{\prime \prime 106}$. En la actualidad integra la hornacina central del retablo una imagen de la Virgen del Pilar de plata, del siglo XIX, siendo las laterales presididas por un san José muy mo-

desto y un Crucificado de finales del siglo XVI, por cuyo formato es evidente que no son originarias de este espacio ${ }^{107}$ (Fig. 9). El resto de la capilla, de reducidas dimensiones, está ornamentada por diferentes cuadros, entre los que destaca el Niño de la Espina, atribuido a José Risueño. Sin embargo, dado el movimiento que han experimentado los enseres de la institución a lo largo de los siglos, es arriesgado relacionarlos directamente con la donación del abad. Al retablo podemos considerarlo como la ampliación y conclusión del modelo de la iglesia, por lo que no sería osado atribuirlo al propio Francisco de Paula. Constituido por tres calle, está integrado por una hornacina en su cuerpo central y culmina en un ático centrado por un óvalo pictórico con la Inmaculada Concepción, según modelo de Murillo, y rematado por una airosa crestería mixtilínea ${ }^{108}$. Sus

104. Actas Capitulares 10, 1763-08-22, 223r-v.

105. Actas Capitulares 6, 1707-06-16, 275v.; Libro de Abades y Canónigos, 119r.; Royo Campos, Abades, 96.

106. Inventario, 1817.

107. El inventario de la abadía reconoce en dicha capilla unas tallas de san José y de la Purísima. Además de un cuadro de san José, otro de la Dolorosa y un cuadrito de la Virgen con el Niño, entre otros enseres. Inventario, 1951-1955, 12-13.

108. En el inventario de la abadía aparece definido como un "altar tallado y dorado: estilo Churrigueresco". Inventario, 1951-1955, 12, 46 y 52. 
calles laterales se dividen por columnas compuestas. Esta asonancia con los retablos colaterales es también visible en su decoración de rocalla y en la forma del altar.

\section{Donación de la imagen de la Asunción de María, a modo de epílogo}

Como colofón nos centramos en la donación de la talla de la Asunción de María, para el templo, siendo abad Miguel Álvarez Cortés. Venía a plasmar en escultura de bulto redondo el relieve del retablo mayor, convirtiéndose en un ejemplo más de la riqueza ornamental que, como hemos visto a lo largo de este artículo, adquirió el Sacro Monte en el Setecientos. Según cabildo de 12 de mayo de 1780, la dádiva la "hazían para nuestra yglesia don Feliz Padilla Barrionuevo y su hermana doña Ysavel"109. El cabildo del Sacro Monte "acordó admitirla y que se dieran a dichos señores las devidas gracias, para lo qual, y su colocación en la yglesia, fueron comisionados los señores doctores don Miguel Álbarez [Álvarez Cortés] y don Manuel de Mesa [López de Mesa]"110. Poco menos de un mes después, en cabildo de 5 de junio de 1780, se hizo pública la propuesta del abad de que "aviendo tratado con el señor Mesa y Feliz de Padilla sobre la colocación y sitio de la imagen de la Asunción, que este quería donar a nuestra yglesia, les parecía que el sitio más proporcionado para dicha ymagen era el altar de san José"1111. Dicha imagen del patriarca, que recordemos que presidía uno de los retablos colaterales, "podía colocarse en el altar donde está el santo Cristo, aunque fuera trocándola por otra ymagen más pequeña del mismo santo"112. Por último, se daba la opción de "fabricarle una nueva capilla en la sala del archivo, que según estaba informado podía hacerse a poca costa y a ello contribuiría el expresado don Feliz"113.

Llama la atención que pocos años después de realizar la imagen de san José se barajase desplazarla del templo estando presente Manuel López de Mesa, quien fuera uno de sus artífices. En ello se advierte un afán por privilegiar a la Asunción de María, por haber sido favorecida por Pedro de Castro, consagrándole el templo, y cuya fiesta era muy celebrada entre los capitulares ${ }^{114}$. Aunque también nos habla de cierta arbitrariedad en la dotación devocional de la iglesia abacial en estos años, en ocasiones condicionada por

\footnotetext{
109. Actas Capitulares 11, 1780-05-12, 411. 110. Actas Capitulares 11.

111. Actas Capitulares 11, 1780-06-05, 413r.

112. Actas Capitulares 11.

113. Actas Capitulares 11.

114. Martínez Medina, Cristianos, 385
} 


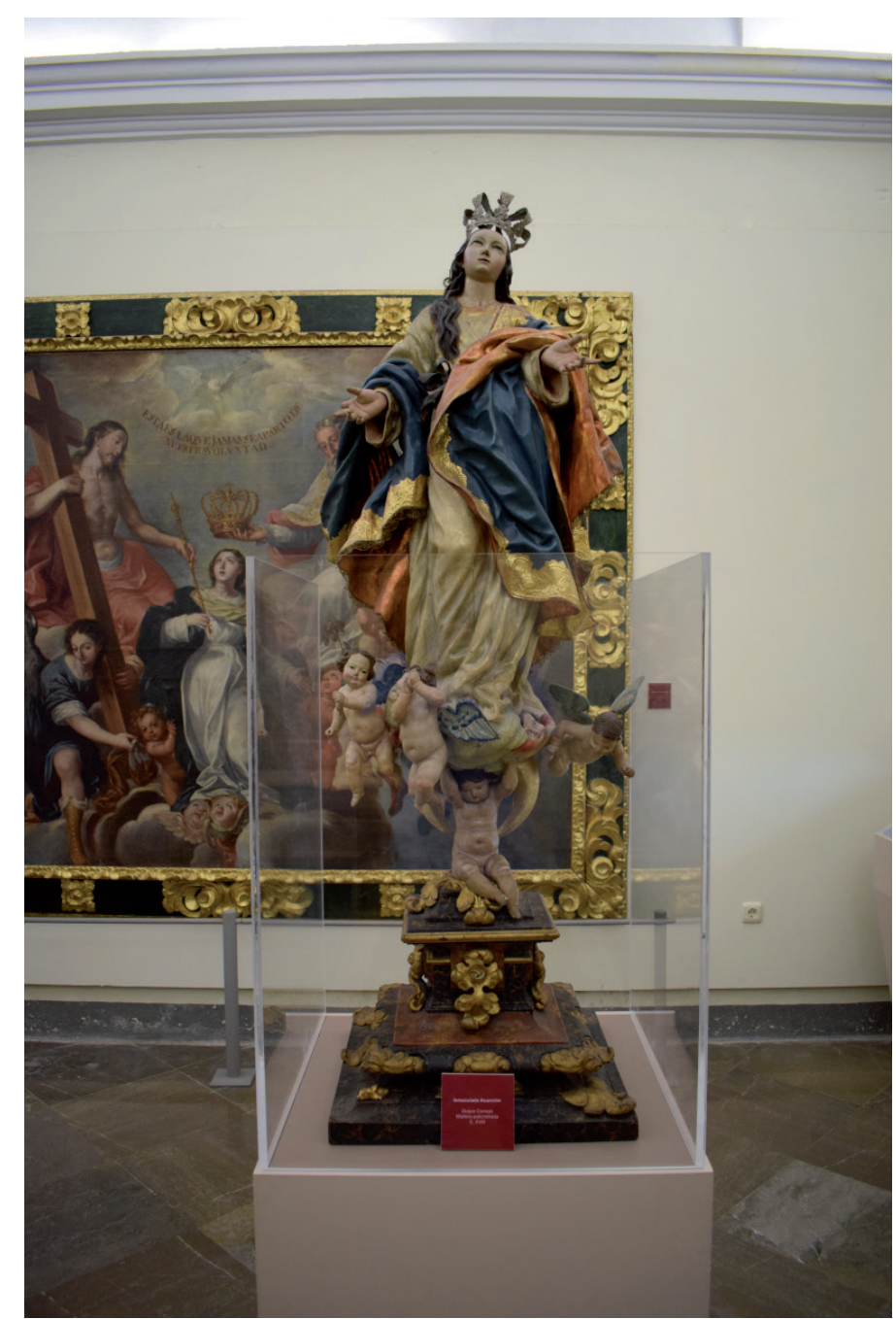

Fig. 10. Torcuato Ruiz del Peral (atribución), Asunción de María, segunda mitad del siglo XVIII. Madera policromada. Abadía del Sacro Monte, Granada. los propios donantes, muchos de los cuales procedían de la alta sociedad andaluza. La Virgen de la Asunción ocupa actualmente la sala III del Museo, junto a la Inmaculada de Duque Cornejo, con la que comparte formato y que había sido donada para las Santas Cuevas por un pariente del canónigo Luis de Viana. Aunque ha tenido diversas atribuciones, la más acertada parece ser la que la relaciona con el escultor de Exfiliana, Torcuato Ruiz del Peral ${ }^{115}$. A ello contribuye el posible parentesco de sus donantes con Diego Nicolás Heredia Barnuevo (o Barrionuevo), original de la vecina localidad de Zújar. Tengamos en cuenta, además de la proximidad geográfica de ambas localidades, la pertenencia al obispado de Guadix, donde fue muy prolífico Ruiz del Peral. Artísticamente, de rostro no excesivamente expresivo, debe

ser estudiada en su conjunto. En ella sobresale un gracioso basamento troncopiramidal, rematado por un ángel, que, sedente a los pies de la Virgen, entre su media luna invertida, la sostiene simulando ser un atlante. Sobre él son igualmente llamativos unos querubines y tres angelillos. La Virgen, con manto volado muy movido, donde quedan restos de un encaje de tela, abre sus brazos, mientras eleva su mirada al cielo. El impulso de su cuerpo es manifestado por el movimiento de su rodilla derecha, adelantada (Fig. 10). Además de por todo lo señalado, como en muchos de los santuarios de montaña postridentinos, esta imagen cobra gran importancia en la abadía, dado que nos invita a la ascesis. No olvidemos que nos encontramos en un templo de peregrinación,

115. En el inventario del año 1817 es reconocida en la sacristía: "vna imagen grande de bulto de la Asunción de María Santísima Nuestra Señora". Inventario, 1817. Esta obra ha sido vinculada al arte de los Mora. María José Martínez Justicia, La vida de la Virgen en la escultura granadina (Madrid: Fundación Universitaria Española, 1996), 292-293. Se asocia a Ruiz del Peral en: José Policarpo Cruz Cabrera, "El legado histórico y artístico sacromontano," en La Abadía del Sacromonte, vida y arte, en las fuentes del cristianismo, eds. Francisco Javier Martínez Fernández, Miguel Luis López-Guadalupe Muñoz, y José Policarpo Cruz Cabrera (Granada: Caja Rural, 2018), 246. 
elevado sobre un promontorio, donde el devoto, tras la purga de sus pegados merecida por su fatigoso camino, busca la elevación de su alma.

\section{Conclusiones}

Más allá de la polémica suscitada por los controvertidos sucesos que avalaron su origen, los retablos de la abadía del Sacro Monte son un importante testimonio de las glorias y desgracias vividas por la institución a lo largo de la historia. No olvidemos que las "guerras católicas granatenses" fueron uno de los debates teológicos de mayor relevancia de la España del siglo XVII, del que formaron parte teólogos reputados como el jesuita morisco P. Ignacio de las Casas y escritores tan universales como Francisco Quevedo ${ }^{116}$. Este devenir ha provocado que los retablos de la abadía, en su naturaleza de sustento y muestrario de la doctrina sacromontana, hayan tenido que mudar y reinventarse a lo largo del tiempo. Esto, lejos de restarles entidad, les convierte en fieles testigos de la capacidad de adaptación del Sacro Monte durante los siglos. Tengamos presente que tuvieron que sobreponerse, entre muchos oprobios, nada menos que a una condena papal. Como muestra de la relevancia que tuvo este asunto en la Iglesia granadina, nos consta que la relectura de su ideario durante el Setecientos afectó también al programa iconográfico de la propia catedral, junto a otras iglesias, siendo el caso más evidente el retablo mayor de la parroquial de San Cecilio, donde estuvo el primer retablo dedicado al patrón de Granada inspirado en el relato de los libros plúmbeos ${ }^{117}$. En este contexto, la exaltación a los mártires del Sacro Monte del retablo mayor y el alegato concepcionista del retablo de la Inmaculada son un destacado reflejo de la resistencia en la abadía a partir especialmente de la segunda mitad del siglo XVIII y en comunión con los descubrimientos de la alcazaba del Albaicín.

116. José Manuel Rico García y Antonio Azaustre Galiana, "Un texto inédito de Quevedo: 'Memorial de don Francisco de Quevedo Villegas dado a la Inquisición General sobre los libros del Monte Santo de Granada'," La Perinola, no. 24 (2020): 71-179.

117. Martínez Medina, Cristianos, 254. 


\section{Referencias}

\section{Fuentes documentales}

Archivo Abadía del Sacro Monte (AAS). Granada. Fondos: Abadía; Colegio.

\section{Fuentes bibliográficas}

Almenara, Miguel Ángel. Pensamientos literales y morales. Valencia: Juan Crisóstomo, 1623.

Barrios Aguilera, Manuel. Los falsos cronicones contra la historia. Granada: Universidad de Granada, 2004.

---. La invención de los libros plúmbeos. Fraude, historia y mito. Granada: Universidad de Granada, 2011.

Barrios Aguilera, Manuel y Mauricio Pastor Muñoz, eds. Razón del juicio seguido contra los falsificadores de la Alcazaba del Albaicín. Granada: Universidad de Granada, 2017.

Cárdenas Bunsen, José. La aparición de los libros plúmbeos y los modos de escribir la historia. Madrid: Iberoamericana-Vervuert, 2018.

Castillo Ferreira, Mercedes. "Música y ceremonia en la Abadía del Sacromonte de Granada (siglos XVII-XIX)." Tesis doctoral, Universidad de Granada, 2009, consultado el 15 de mayo de 2020, https://dialnet.unirioja.es/servlet/tesis?codigo $=65588$

"Crónica del Centro." Boletín del Centro artístico de Granada, no. 6 (1886): 1.

Cruz Cabrera, José Policarpo. "El legado histórico y artístico sacromontano." En La Abadía del Sacromonte, vida y arte, en las fuentes del cristianismo, editado por Francisco Javier Martínez Fernández, Miguel Luis López-Guadalupe Muñoz, y José Policarpo Cruz Cabrera, 135-326. Granada: Caja Rural, 2018.

Gallego Burín, Antonio. El Barroco granadino. Granada: Comares, 1987.

García Valverde, María Luisa. "La donación del arzobispo don Pedro de Castro al Sacromonte: el inventario de sus bienes." Cuadernos de Arte, no. 27(1996): 283-295.

Gila Medina, Lázaro. "Aproximación a la vida y obra del pintor y estofador alcalaíno-granadino Pedro Raxis." Archivo Español de Arte, no. 304 (2003): 389-406.

---. "Los comienzos -bautismo y entorno familiar- y los últimos momentos -testamento y sepelio- del escultor Bernabé de Gaviria." Cuadernos de Arte, no. 38 (2007): 305-315.

---. "Bernabé de Gaviria: continuación y ruptura de los ideales de Rojas." En La escultura del primer naturalismo en Andalucía e Hispanoamérica (1580-1625), editado por Lázaro Gila Medina, 177-207. Madrid: Arco Libros, 2010.

Gómez-Moreno Calera, José Manuel. La arquitectura religiosa granadina en la crisis del Renacimiento (1560-1650). Granada: Universidad, 1989.

---. El Arquitecto granadino Ambrosio de Vico. Granada: Universidad de Granada, 1992.

---. "Evolución de la retablística granadina entre los siglos XVI y XVII." En La escultura del primer naturalismo en Andalucía e Hispanoamérica (1580-1625), editado por Lázaro Gila Medina, 241-272. Madrid: Arco Libros, 2010. 
Gómez Román, Ana María. "Torcuato Ruiz del Peral y el devenir de la escultura en Granada hasta mediados del siglo XIX." Boletín del Centro Pedro Suárez, no. 21 (2008): 327-398.

Hagerty, Miguel José. Los libros plúmbeos del Sacromonte. Granada: Comares, 2007.

Isla Mingorance, Encarnación. Camarín y retablo de Nuestra Señora del Rosario. Granada, 1990.

López-Guadalupe Muñoz, Juan Jesús. "Del Barroco avanzado al Neoclasicismo en la retablística granadina del Setecientos. Apuntes para una monografía." Cuadernos de Arte, no. 29 (1998): 89-106.

---. "Escultura y escultores en Granada en la época de Ruiz del Peral. Modelos, talleres y síntesis evolutiva." Boletín del Centro Pedro Suárez, no. 21 (2008): 291-326.

Martínez Justicia, María José. La vida de la Virgen en la escultura granadina. Madrid: Fundación Universitaria Española, 1996.

Martínez Medina, Francisco Javier. Cristianos y musulmanes en la Granada deI XVI, una ciudad intercultural. Granada: Facultad de Teología, 2016.

Mora, Gloria y Joaquín Álvarez Barrientos. "Las falsificaciones granadinas del siglo XVIII. Nacionalismo y arqueología." Al-Oantara XXIV, no. 2 (2003): 533-546.

---. "Las falsificaciones granadinas del siglo XVIII. Nacionalismo y Arqueología." En Los plomos del Sacromonte. Invención y tesoro, editado por Manuel Barrios Aguilera y Mercedes García-Arenal, 521-532. Valencia: Universidad de Valencia, 2006.

Moreno Garrido, Antonio y Ana María Pérez Galdeano. "Los Países Bajos y su influencia en la obra gráfica peninsular del siglo XVII." En Arte y Cultura en la Granada Renacentista y Barroca: relaciones e influencia, editado por Policarpo Cruz Cabrera, 281-306. Granada: Universidad de Granada, 2014.

Ollero Pina, José Antonio. "Don Pedro de Castro, arzobispo de Sevilla (1610-1623), una relación conflictiva." En Realidades conflictivas. Andalucía y América en la España del Barroco, editado por Miguel Luis López-Guadalupe y Juan José Iglesias Rodríguez, 95-116. Sevilla: Universidad de Sevilla, 2012.

Orozco Díaz, Emilio. El pintor fray Juan Sánchez Cotán. Granada: Universidad de Granada, 1993.

Palomino Ruiz, Isaac. "Patrocinio y mecenazgo de Gregorio Eugenio de Espínola sobre templos granadinos." En El Barroco: Universo de Experiencias, editado por María del Amor Rodríguez Miranda y José Antonio Peinado Guzmán, 66-86. Córdoba: Asociación Hurtado Izquierdo, 2017.

Peinado Guzmán, José Antonio. "El Sacro Monte como institución inmaculista granadina en Ios siglos XVII y XVIII." Revista del CEHGR, no. 25 (2013): 181-200.

Peinado Guzmán, José Antonio, e Isaac Palomino Ruiz. "Piezas inéditas de la Abadía del Sacro Monte en Granada." Ucoarte. Revista de Teoría e Historia del Arte, no. 3 (2014): 67-84.

---. "Referencias documentales en torno a la dotación artística primigenia de la abadía del Sacro Monte en Granada." Revista de Humanidades, no. 29 (2016): 37-60.

Pérez Galdeano, Ana María. La Historia de la Abadía del Sacromonte a través de sus grabados. Granada: IDEAL y Fundación Abadía del Sacromonte, 2016.

Pita Andrade, José Manuel. Museo del Sacro Monte. Vol. 20 de Guías de los Museos de España. Granada: Ministerio de Educación Nacional, Dirección General de Bellas Artes, 1964.

Ramos López, José de. El Sacro-Monte de Granada. Madrid: Fortanet, 1883.

---. Restablecimiento de los estudios de derecho en el insigne colegio del Sacro-Monte de Granada. Granada: José López Guevara, 1897. 
Revista de historia y genealogía española. Vol. 1. Madrid: Sucesores de Rivadeneyra, 1912.

Rico García, José Manuel, y Antonio Azaustre Galiana. "Un texto inédito de Quevedo: 'Memorial de don Francisco de Quevedo Villegas dado a la Inquisición General sobre los libros del Monte Santo de Granada'." La Perinola, no. 24 (2020): 71-179.

Rodríguez Ruiz, Delfin. "De la utopía a la Academia. El tratado de arquitectura civil de José de Hermosilla." Fragmentos, no. 3 (1989): 58-80.

Roldán Hervás, José Manuel. "Arqueología y fraude en la Granada del siglo XVIII: Juan de Flores y las excavaciones del Albayzín." Zephyrvs, no. 85 (1984): 377-396.

Roldán, Manuel Jesús. "Ángeles que dan luz." Pasión en Sevilla, ABC, julio de 2020. Consultado el 17 de octubre de 2020. https://sevilla.abc.es/pasionensevilla/actualidad/noticias/angeles-dan-luz-los-grandes-acompanantes-los-retablos-180874-1595191019.html.

Royo Campos, Zótico. Abades del Sacro-Monte. Granada: Anel, 1964.

---. Bellezas Sacromontanas. Granada: Anel, 1967.

Sambricio, Carlos. "José de Hermosilla y el ideal historicista de la llustración." Goya, no. 159 (1980): 140-151.

Sánchez Gordillo, Alonso. Memorial sumario de los arzobispos de Sevilla y otras obras. Facsímil. Sevilla: Ayuntamiento, 2003.

Sánchez Ocaña, Juan. El Sacro Monte de Granada, imaginación y realidad. Granada: Ayuntamiento, 2007.

Sotomayor, Manuel. Don Juan de Flores y Oddouz. Pícaro y Mártir: cultura y picaresca en la Granada de la llustración. Granada: Universidad de Granada, 2008.

---. "Los fundamentos histórico-eclesiásticos del Sacromonte: de Santiago y sus varones apostólicos a los hallazgos de Valparaíso." En ¿La historia inventada? Los libros plúmbeos y el legado sacromontano, editado por Manuel Barrios Aguilera y Mercedes García-Arenal, 29-45. Granada: Universidad de Granada, 2008.

Valverde Tercedor, José María. "El arte como legado, patrocinio y mecenazgo en la Abadía del Sacro Monte. Siglos XVII y XVIII." Tesis doctoral, Universidad de Granada, 2019, consultado el 17 de mayo de 2020, https://dialnet.unirioja.es/servlet/tesis?codigo=221457

---. "El retablo mayor de la Abadía del Sacro Monte de Granada y su conjunto escultórico de Domingo Cabrera (1746-1748). Datación, documentación y contextualización histórica." Anales del Instituto de Investigaciones Estéticas, no. 116 (2020): 93-128.

---. "Cofradías y religiosidad popular en la Abadía del Sacro Monte." En III Simposio Internacional de Historia de Semana Santa de Granada (Granada, 22 de febrero de 2020), coordinado por Francisco Javier Crespo Muñoz y José María Valverde Tercedor, 79-122. Granada: Nuevo Inicio, 2020. 